\title{
Black shale deposition on the northwest African Shelf during the Cenomanian/Turonian oceanic anoxic event: Climate coupling and global organic carbon burial
}

\author{
Sadat Kolonic, ${ }^{1,2}$ Thomas Wagner, ${ }^{1}$ Astrid Forster, ${ }^{3}$ Jaap S. Sinninghe Damsté, ${ }^{3,4}$ \\ Ben Walsworth-Bell, ${ }^{5}$ Elisabetta Erba, ${ }^{5}$ Steven Turgeon, ${ }^{6,7}$ Hans-Jürgen Brumsack, ${ }^{6}$ \\ El Hassane Chellai, ${ }^{8}$ Harilaos Tsikos, ${ }^{9,10}$ Wolfgang Kuhnt, ${ }^{11}$ and Marcel M. M. Kuypers ${ }^{12}$ \\ Received 9 July 2003; revised 9 August 2004; accepted 20 August 2004; published 4 February 2005.
}

[1] High-resolution geochemical records from a depth transect through the Cenomanian/Turonian $(\mathrm{C} / \mathrm{T})$ Tarfaya Basin (northwest African Shelf) reveal high-amplitude fluctuations in accumulation rates of organic carbon (OC), redox-sensitive and sulphide-forming trace metals, and biomarkers indicative of photic zone euxinia. These fluctuations are in general coeval and thus imply a strong relationship of OC burial and water column redox conditions. The pacing and regularity of the records and the absence of a prominent continental signature suggest a dynamic depositional setting linked to orbital and higher-frequency forcing. Determining the dominant frequency depends on the definition of the most pronounced oceanic anoxic event (OAE2) and its duration. We propose that eccentricity is the main forcing factor at Tarfaya and controlled fluctuations in wind-driven upwelling of nutrient-rich, oxygen-depleted intermediate waters from the adjacent Atlantic and the periodic development of photic zone and bottom water euxinia on the midCretaceous northwest African shelf. Accumulation records clearly identify the basin center as the primary site of sediment deposition with highest temporal variability and an up to six-fold increase in OC burial from $\sim 2 \mathrm{~g} / \mathrm{m}^{2}$. yr prior to the OAE2 to $\sim 12 \mathrm{~g} / \mathrm{m}^{2} \cdot \mathrm{yr}$ during the OAE2. Photic zone and bottom water euxinia alternated with periods of greater oxygenation of the water column in response to climate forcing. Mass balance calculations imply that $\sim 2 \%$ of the overall global excess OC burial associated with the OAE2 was deposited in the Tarfaya Basin, an area that represented only $\sim 0.05 \%$ of the total global $\mathrm{C} / \mathrm{T}$ ocean floor. In fact, the lateral extent of similar black shales along the African continental margin indicates that this part of the ocean contributed significantly to the global increase in organic carbon burial during the OAE2.

Citation: Kolonic, S., et al. (2005), Black shale deposition on the northwest African Shelf during the Cenomanian/Turonian oceanic anoxic event: Climate coupling and global organic carbon burial, Paleoceanography, 20, PA1006, doi:10.1029/2003PA000950.

\section{Introduction}

[2] The Cretaceous was an extraordinary period in Earth history, when organic carbon (OC)-rich sediments were repeatedly deposited on a basin-wide or even global scale [e.g., Hay et al., 1999; Larson and Erba, 1999; Jones and Jenkyns, 2001; Leckie et al., 2002]. Three distinct intervals of particularly high $\mathrm{OC}$ burial rates are distinguished in the marine record, occurring during the Aptian-Albian, the

\footnotetext{
${ }^{1}$ Faculty of Geosciences, University of Bremen, Bremen, Germany.

${ }^{2}$ Now at Shell International Exploration and Production, Rijswijk, Netherlands.

${ }^{3}$ Department of Marine Biogeochemistry and Toxicology, Royal Netherlands Institute for Sea Research, Den Burg, Netherlands.

${ }^{4}$ Also at Institute of Paleoenvironment and Paleoclimate, Department of Geochemistry, University of Utrecht, Utrecht, Netherlands.

${ }^{5}$ Ardito Desio Department of Earth Sciences, University of Milan, Milan, Italy.

Copyright 2005 by the American Geophysical Union. 0883-8305/05/2003PA000950\$12.00
}

Cenomanian/Turonian $(\mathrm{C} / \mathrm{T})$ transition, and the ConiacianSantonian. These periods of enhanced global sequestration of OC, termed oceanic anoxic events (OAEs) [Schlanger and Jenkyns, 1976; Jenkyns, 1980], favored the formation of petroleum source rocks and affected the mid-Cretaceous climate by effectively reducing atmospheric $p \mathrm{CO}_{2}[$ Arthur et al., 1988; Kuypers et al., 1999; Wallmann, 2001]. Although new insights into the functioning and pacing of

\footnotetext{
${ }^{6}$ Institute for the Chemistry and Biology of the Marine Environment, Carl von Ossietzky University of Oldenburg, Oldenburg, Germany.

${ }^{7}$ Now at Chemical and Isotopic Mass Spectrometry Group, Oak Ridge National Laboratory, Oak Ridge, Tennessee, USA.

${ }^{8}$ Faculté des Sciences Semlalia, Départment de Géologie, Cadi Ayyad University, Marrakech, Morocco.

${ }^{9}$ Department of Earth Sciences, University of Oxford, Oxford, UK.

${ }^{10}$ Now at Department of Geology and Petroleum Geology, University of Aberdeen, Aberdeen, UK.

${ }^{11}$ Department of Geosciences, Christian-Albrechts University of Kiel, Kiel, Germany.

${ }^{12}$ Department of Biogeochemistry, Max Planck Institute for Marine Microbiology, Bremen, Germany.
} 
the mid-Cretaceous ocean-atmosphere system have been gained in recent years [e.g., Hay and DeConto, 1999; Larson and Erba, 1999; Jones and Jenkyns, 2001; Leckie et al., 2002; Wallmann, 2001; Bice and Norris, 2002; Kuypers et al., 1999, 2002; Hofmann et al., 2003; Erba and Tremolada, 2004; Wagner et al., 2004], the environmental factors that triggered and sustained these OAEs remain controversial. Increased submarine igneous activity associated with the formation of the Caribbean Oceanic Plateau, resulting in enhanced hydrothermal supply of biolimiting metals and more efficient nutrient cycling due to a breakdown in thermal stratification, has been put forward as one possible trigger mechanism [Larson and Erba, 1999]. Meanwhile, Kuypers et al. [2002] demonstrated that deep water black shale formation in the $\mathrm{C} / \mathrm{T}$ low-latitude $\mathrm{N}$ Atlantic most likely resulted from a combination of enhanced organic matter $(\mathrm{OM})$ preservation due to increased anoxia, and increased primary productivity.

[3] The most pronounced OAE (hereafter referred to as the OAE2) occurred $\sim 94 \mathrm{Myr}$ ago, during the $\mathrm{C} / \mathrm{T}$ transition, and is regarded as the type example of the Mesozoic OAEs. The OAE2 was associated with large and short-term changes in atmospheric $p \mathrm{CO}_{2}$ [e.g., Kuypers et al., 1999], extinction of marine biota [e.g., Kuhnt and Wiedmann, 1995; Gale et al., 2000], and ocean chemistry turnover [e.g., Brumsack, 1980; Kuypers et al., 2002]. The OAE2 is characterized by a distinct positive excursion in the stable carbon-isotopic record $\left({ }^{13} \mathrm{C}\right)$ of marine carbonate and marine and terrestrial OM [Schlanger and Jenkyns, 1976] This positive $\delta^{13} \mathrm{C}$ shift is conventionally related to excess burial of $\mathrm{OC}$ [Schlanger and Jenkyns, 1976; Jenkyns, 1980; Arthur et al., 1988].

[4] The deposition of thick OC-rich black shales indicates that the N African Continental Margin (see review in the work of Lüning et al. [2004]) and the northwest African Shelf in particular was a major site of OC burial during OAE2 [Kuhnt et al., 2001; Kuypers et al., 2002]. The Tarfaya Basin on the northwest African Shelf, for example, contains more than $500 \mathrm{~m}$ of Upper Cretaceous laminated OC-rich biogenic sediments [Leine, 1986]. These black shales were deposited with exceptionally high sedimentation rates [Kuhnt et al., 2001], allowing investigation of paleoceanographic changes and climate events on a centennial timescale resolution.

[5] This study aims to reconstruct the mechanisms of black shale deposition on the northwest African Shelf during the $\mathrm{C} / \mathrm{T}$ transition with respect to climate coupling and global organic carbon burial. On the basis of a reconsideration of the OAE2 definition for the Tarfaya sections we present centennial- to millennial-scale organic and inorganic geochemical records. These records are from four sites located along a NW-SE depth transect through the Tarfaya Basin, the reference site for the age model being drill site S75 previously investigated by Kuhnt et al. [1997, 2001, 2004]. This study specifically addresses (1) trends of OC accumulation before, during, and after the OAE2, (2) the associated development and coupling of deep and photic zone anoxia, and (3) the mechanisms that drove black shale formation in a spatiotemporal perspective. On the basis of this new comprehensive set of data we finally discuss the general importance of the mid-Cretaceous northwest African Shelf as a primary site of global OC burial.

\section{Material and Methods}

[6] The samples were obtained from four sites along a NW-SE transect through the Tarfaya Basin (Figure 1), establishing a paleotransect of about $120 \mathrm{~km}$ in length connecting the deepest part of the basin (Sites S13 and S57, $\sim 250-300 \mathrm{~m}$ paleowater depth) with transitional locations (Site S75) and a proximal location close to the paleocoastline (Mohammed Plage, Mpl, 50-100 m paleowater depth). Sample material from S13, S57 and S75 was obtained from cores drilled by the Moroccan State Oil Company (ONAREP) and Shell during the late 1970s and early 1980s [Leine, 1986]. Sediment slices between 2 and $7 \mathrm{~cm}$ thick on average were taken from the investigated $\mathrm{C} / \mathrm{T}$ core intervals. $\mathrm{Mpl}$ material was obtained from a coastal exposure.

[7] All samples were dried and ground in an agate mortar before total (TC) and organic carbon (TOC) contents were measured using a LECO CS-300 carbon-sulphur analyzer (precision of measurements $\pm 3 \%$ ). For TOC determinations, inorganic carbon was carefully removed by repetitive addition of $0.25 \mathrm{~N} \mathrm{HCl}$. The $\delta^{13} \mathrm{C}$ values $( \pm 0.1 \%$ versus Vienna Peedee belemnite (VPDB)) were measured on decalcified sediments, using automated online combustion followed by conventional isotope-ratio mass spectrometry. For biomarker analysis, pulverized samples (5 to $10 \mathrm{~g}$ ) were extracted with an accelerated solvent extractor (ASE) (temperature: $100^{\circ} \mathrm{C}$; pressure: 100 psi; DCM:MeOH: 9:1). For most samples (i.e., from the S13, S75 and Mpl sites) an aliquot of the total extract was used for direct Raney Nickel desulphurization [Petit and van Tamelen, 1962; Sinninghe Damsté et al., 1994] and subsequent hydrogenation in order to analyze both free and S-bound biomarkers in a single step. In the case of S57 extracts were first fractionated into an apolar and polar fraction and the polar fraction was subsequently desulphurized using Raney Nickel [Kuypers et al., 2002]. Samples were analyzed by gas chromatography-mass spectrometry (GC-MS) using a Hewlett-Packard 5890 gas chromatograph interfaced with a VG Autospec Ultima Q mass spectrometer operated at $70 \mathrm{eV}$ with a mass range $\mathrm{m} / \mathrm{z} 50-800$ and a cycle time of $1.8 \mathrm{~s}$ (resolution = 1000). Compounds were identified using both GC relative retention times and mass spectra by comparison with literature data and reference standards. For compoundspecific $\delta^{13} \mathrm{C}$ sulphur-bound phytane measurements, the polar fractions were first treated by Raney Nickel desulphurization, in order to release sulphur-bound hydrocarbons, followed by column separation and hydrogenation of the apolar fractions to yield phytane. All compoundspecific carbon-isotope measurements were carried out at least in duplicate $(\sigma= \pm 0.03$ to 0.58$)$ as described by Kuypers et al. [2002] and the mean $\delta^{13} \mathrm{C}$ values for each sample are presented in the usual $\delta$ notation versus the VPDB standard. The analytical accuracy of the irm-GC-MS 




Figure 1. (a) Distribution of unfolded Mesozoic and Cenozoic coastal basins containing OC-rich $\mathrm{C} / \mathrm{T}$ black shales along the northwest African continental margin (modified from Lüning et al. [2004]). (b) Paleogeographic map of the Tarfaya Basin with the positions of the studied sites along a depth transect from the basin center (S13, S75, S57) close to the paleocoastline (Mpl). Abbreviations are as follows: AgB, Agadir Basin, AtB, Atlas Basin; EB, Essaouira Basin; DB, Doukkala Basin; TB, Taddla Basin.

was monitored by adding an internal standard of known isotopic composition to every individual sample injection.

[8] Major, minor and trace element composition was determined using either XRF spectrometry on fused-borate glass beads (S13 and S57) or by inductively coupled plasma-atomic emission spectrometry (ICP-AES; S75 and Mpl). XRF calibration curves were based on international standard reference material. Measured values were within $3 \%$ of the accepted value and standard deviation of three replicates was less then $3 \%$. For ICP-AES, about $50 \mathrm{mg}$ of sample was digested in a mixture of $3 \mathrm{~mL} \mathrm{HNO3} \mathrm{(65 \% ),}$
$2 \mathrm{~mL} \mathrm{HF} \mathrm{(40 \% )} \mathrm{and} 2 \mathrm{~mL} \mathrm{HCl} \mathrm{(36 \% )} \mathrm{of} \mathrm{suprapure} \mathrm{quality}$ at $200^{\circ} \mathrm{C}$ and $30 \mathrm{kbar}$ in closed Teflon vessels [Heinrichs et al., 1986]. After drying by evaporation, the residue was re-dissolved with $0.5 \mathrm{~mL} \mathrm{HNO}_{3}(65 \%)$ and $4.5 \mathrm{~mL}$ demonized water. Subsequently, the solutions were analyzed with ICP-AES, and the results checked with international standard reference material; relative standard deviations in duplicate measurements were below 3\%.

[9] Sedimentation rates (SR) and mass accumulation rates (MAR) of $\mathrm{OC}, \mathrm{CaCO}_{3}$, trace metals, and biomarkers were calculated for each individual sedimentary cycle as defined by Kuhnt et al. [2004] assuming that (1) SRs were linear within each sedimentary cycle and that (2) each of them represents one short eccentricity cycle of $\sim 100 \mathrm{kyr}$. The first assumption may bear some inaccuracy with respect to potential short-term fluctuations in sedimentation rate; however, the precise assessment of such fluctuations is probably even more speculative in mid-Cretaceous sediment sections and therefore has been omitted. The line of arguments leading to the conclusion on the nature of the main orbital frequency is discussed in a separate section below. To calculate bulk MARs dry bulk density (DBD) instead of wet bulk density and porosity was used following $\mathrm{MAR}_{\text {bulk }}=\mathrm{LSR} \times \mathrm{DBD}$ with $\mathrm{DBD}$ obtained from core density logs published for sites S13 and S75 [Leine, 1986; Kuhnt et al., 1997]. At these two sites, DBD reveals an excellent linear positive correlation with TOC $\left(\mathrm{r}^{2}=0.95\right)$. Given the close similarity in TOC records across the four study sites we, therefore, assume that the same relationship is valid for sites S57 and Mpl. Thus DBD was calculated from the TOC records of the latter two sites.

\section{Geological Setting, Lithology, and Organic Matter Composition}

[10] The Tarfaya Basin is situated southwest of the AntiAtlas Mountains. It extends into the Tindouf Basin to the east and the Sénégal Basin to the south; its western margin is defined by the East Canary Ridge. The basement is composed of folded Precambrian and Paleozoic rocks, which are uncomfortably overlain by Mesozoic sediments whose thickness locally exceeds $12 \mathrm{~km}$ [Heyman, 1989]. Covering a total area of about $170,000 \mathrm{~km}^{2}$, the basin hosts one of the largest oil-shale deposits in the world [Amblés et al., 1994], reaching an exceptional thickness of up to $500 \mathrm{~m}$. Detailed and comprehensive geological descriptions of this area have been provided by Martinis and Visintin [1966], Wiedmann et al. [1978], von Rad and Arthur [1979], von Rad and Einsele [1980], Ranke et al. [1982], and Heyman [1989].

[11] Detailed lithological descriptions of the Tarfaya sections are given in the work of Leine [1986], Kuhnt and Wiedmann [1995], Kuhnt et al. [1997], Luderer [1999] and Albani El et al. [1999]. The C/T black shales of Tarfaya reveal distinct similarities in bedding structures, composition, and cyclicity, which allow basin-wide correlation of individual beds [e.g., Kuhnt et al., 1997]. Sedimentary bedding cycles mainly consist of two types of lithology, i.e., dark brownish gray, laminated, kerogenous chalks that 


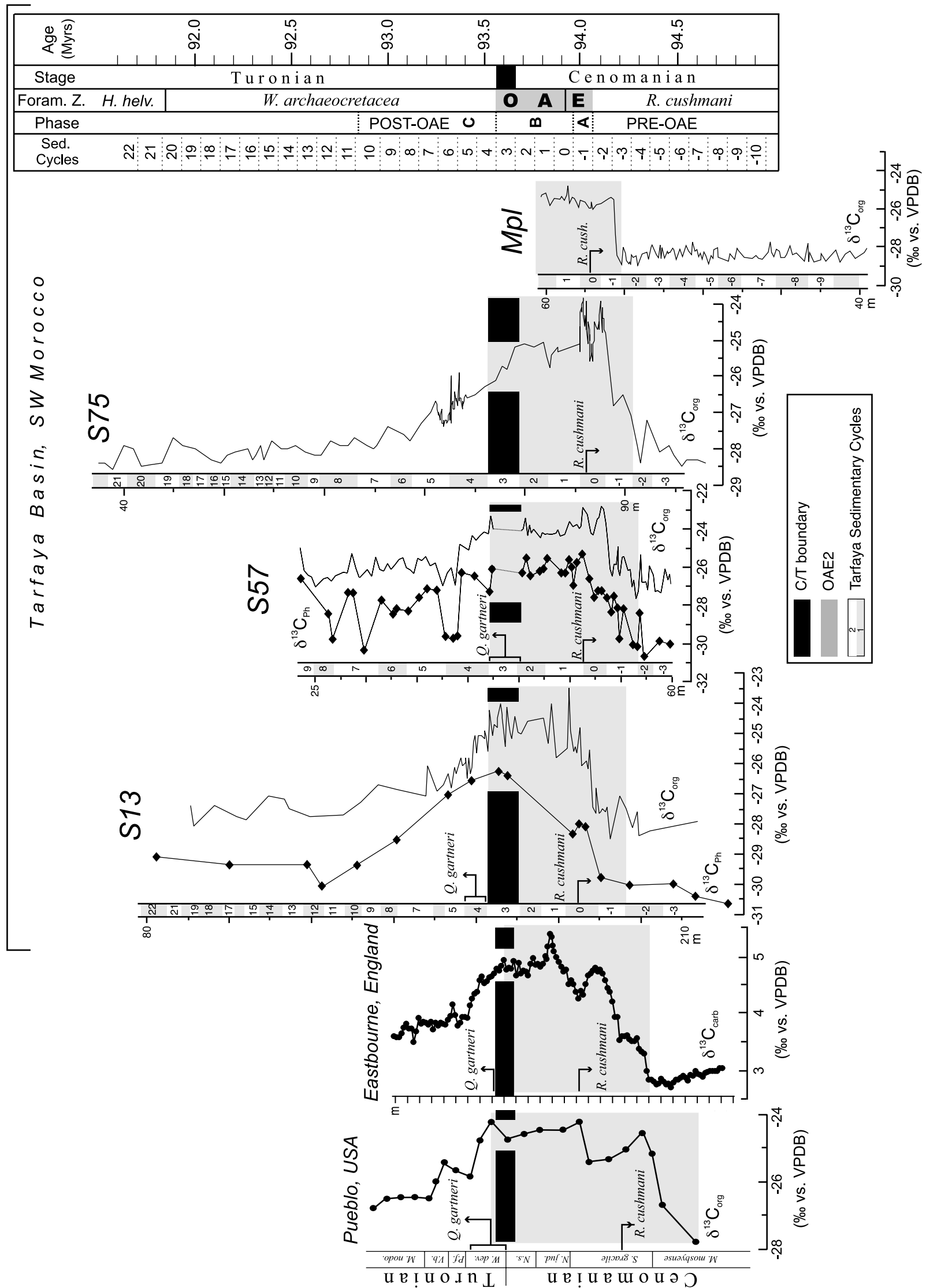

光 
alternate with decimeter-scale, nonlaminated, lighter colored, often nodular limestones with far lower kerogen contents. Beds with up to meter-size carbonaceous concretions, lenses of chert and siliceous limestone, and tempestite beds showing characteristic hummocky cross-stratification structures [Albani El et al., 1999] form distinct interlayers that can be traced over tens of kilometers and serve as excellent correlation levels.

[12] Main components of the kerogen-rich chalks are fecal pellets containing abundant calcareous nannofossils, foraminiferal tests, kerogen-flasers, and a carbonate-matrix mainly composed of nannofossils and micrite [Leine, 1986]. A detailed description of the OM in the Tarfaya black shales is provided by Kolonic et al. [2002]. Accordingly, the Tarfaya black shales are characterized by high hydrogen indices between 400 and $800(\mathrm{mgHC} / \mathrm{gTOC})$, indicating a dominant marine origin of sedimentary OM (type I-IIS kerogen). Organic petrological studies confirm the latter conclusion, and show that the bulk sedimentary $\mathrm{OM}$ is almost entirely composed of a brightly fluorescing groundmass with high abundances of lamalginite and bituminite, while detrital vitrinite and inertinite are only present in trace amounts. The persistence of low $\mathrm{T}_{\max }$ values obtained from Rock-Eval pyrolysis $\left(404-425^{\circ} \mathrm{C}\right)$ supports an immature to very early mature level of thermal maturation in terms of hydrocarbon (HC) generation. Total lipid analyses performed after desulphurization of the total extract show that biomarkers mostly comprise short-chain $\left(\mathrm{C}_{16}-\mathrm{C}_{22}\right)$ and long-chain $\left(\mathrm{C}_{25}-\mathrm{C}_{35}\right) n$-alkanes with no odd-over-even predominance, together with steranes, hopanoids and acyclic isoprenoids [Kolonic et al., 2002]. Flash pyrolysis GC-MS analysis of the kerogen confirms the aliphatic nature of the bulk OC. Phenols and methoxyphenols, both pyrolysis products of lignin and thus indicative of higher plant biopolymers [Saiz-Jimenez and de Leeuw, 1984, 1986], are only present in trace amounts [Kolonic et al., 2002].

\section{Basin Biostratigraphic Framework and Cyclostratigraphy}

[13] This study focuses on the chronostratigraphic interval between $\sim 92$ and $\sim 95 \mathrm{Myr}$ and spans three planktonic foraminiferal zones (PFZs; Figure 2), i.e., (1) the middle to late Cenomanian Rotalipora cushmani PFZ, (2) the latest Cenomanian to earliest Turonian Whiteinella archaeocretacea PFZ, and (3) the early to middle Turonian Helvetoglobotruncana helvetica PFZ [Robaszynski and Caron, 1995]. The planktonic foraminiferal biostratigraphy of Kuhnt et al. [1990, 1997] and Luderer [1999] was applied to S13 (top $R$. cushmani to base $H$. helvetica PFZ) and S75 (top $R$. cushmani to base $H$. helvetica PFZ). New planktonic foraminiferal biostratigraphic data were used for S57 (top $R$. cushmani to mid- $W$. archaeocretacea PFZ) [Tsikos et al., 2004]. For Mpl the biostratigraphy of Luderer [1999] was applied (middle $R$. cushmani to base $W$. archaeocretacea zone). This planktonic foraminiferal biostratigraphy was supplemented by calcareous nannofossil data for site S13 (J. Mutterlose, personal communication, 2003) and site S57 [Tsikos et al., 2004].

[14] In an earlier work, Kuhnt et al. [1997] developed a cyclostratigraphic model for the late Cenomanian to early Turonian sections at Tarfaya using high-resolution density records from various drill sites, biostratigraphic data on foraminiferal biozones, and indicative global trends in the bulk carbon isotope record (Figure 2). Applying time series analysis to density logs from six drill sites (including S13 and S75 investigated in this study), thirty-two sedimentary cycles were identified, each representing a couplet of one carbonate-rich and one OC-rich bed. By definition the cycle containing the age-diagnostic last occurrence (LO) of R. cushmani ( 293.9 Myr) was designated as cycle 0 . According to this earlier work the time frequency of sedimentary cycles -1 to +9 was attributed to obliquity forcing, followed by a higher, probably precessional forcing in the upper part of the record (cycles 10 and above). In this study we combine this first cyclostratigraphic model with new data from biostratigraphy and stable carbon isotopes to (1) extend the correlation of the Tarfaya cycles from the deepest part of the basin (S13) toward the paleocoastline $(\mathrm{Mpl})$, and to (2) reconsider the main frequency band documented in the sedimentary cycles. At Mpl, bedding cycles were identified using detailed lithological descriptions obtained during fieldwork (see Kolonic et al. [2002] for detailed lithological log). In contrast to Kuhnt et al. [1997], the C/T boundary is placed in the upper part of cycle 3 using the first occurrence (FO) of the nannofossil Quadrum gartneri (the lowermost observation of this marker species in the Tarfaya Basin is just above a large coring gap at S57 (see Tsikos et al. [2004] for further stratigraphic details), resulting in the absence of cycle 3 . As such this event cannot be placed with more confidence.

\section{Results and Discussion}

\subsection{Cenomanian-Turonian $\delta^{13} \mathrm{C}$ Excursion at Tarfaya}

[15] The OAE2 $\delta^{13} \mathrm{C}$ excursion is characterized by several spikes and nudges in the various key sections reported from the Atlantic and Tethyan realms [Gale et al., 1993; Tsikos et al., 2004]. Despite these local features it has been suggested that the general trend of the excursion is global in nature

Figure 2. Carbon isotope records (permil versus V-PDB) of bulk organic carbon and key bioevents from the investigated Tarfaya sites in comparison to the $\mathrm{C} / \mathrm{T}$ reference sites at Pueblo (Colorado, USA) and Eastbourne (Sussex, UK). C/T boundary placed at Pueblo and Eastbourne using ammonites [Kennedy et al., 2000; Gale et al., 1993], and at Tarfaya using the FO Q. gartneri (nannofossil). The $\delta^{13} \mathrm{C}$ phases of Kuypers et al. [2002] and the position of the OAE2 (phases A and B) are shown, as are the ages assigned to the Tarfaya cycles (see text). Pueblo data (except FO Q. gartneri) from Kennedy et al. [2000] and references therein. Eastbourne $\delta^{13} \mathrm{C}_{\text {carb}}$, S57 $\delta^{13} \mathrm{C}_{\text {org }}$ and $\delta^{13} \mathrm{C}_{\mathrm{Ph}}$ from Tsikos et al. [2004]; S75 $\delta{ }^{13} \mathrm{C}_{\text {org }}$ from Kuhnt et al. [2001, 2004]. LO R. cushmani at Eastbourne and S57 from Tsikos et al. [2004], at S13 and S75 from Kuhnt et al. [1997, 2004], and at Mpl from Luderer [1999]. FO Q. gartneri at S13 from J. Mutterlose (personal communication, 2003) and at S57 from B. Walsworth-Bell (unpublished data, 2004). 


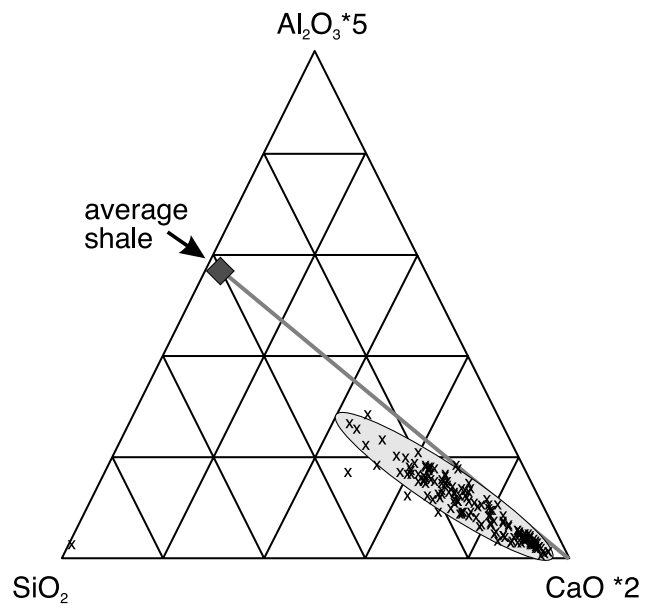

Figure 3. Triangle plot showing the major chemical components of the Tarfaya black shale (data from S13 and $\mathrm{S} 57$, as $\mathrm{SiO}_{2}$ was not determined for $\mathrm{S} 75$ and $\mathrm{Mpl}$ ). Arbitrary multipliers $\left(\mathrm{Al}_{2} \mathrm{O}_{3} \cdot 5\right.$ and $\left.\mathrm{CaO}_{2} \cdot 2\right)$ are introduced in order to center the data on the graph. The chemical composition of the Tarfaya shales is very similar to a carbonate-diluted average shale [Wedepohl, 1971].

and can be divided into three principle phases [Kuypers et al., 2002]: phase $\mathrm{A}$, a rapid increase in $\delta^{13} \mathrm{C}$ values in the uppermost $R$. cushmani biozone; phase $\mathrm{B}$, a plateau of maximum $\delta^{13} \mathrm{C}$ values in the lower $W$. archaeocretacea biozone; and phase $\mathrm{C}$, a gradual return to pre-excursion values, which ends in the $H$. helvetica biozone. It is commonly accepted that the positive excursion in the $\delta^{13} \mathrm{C}$ values (phases A and B) reflects a prominent change in the global atmospheric-oceanic pool of inorganic carbon resulting from a global increase in the burial rate of ${ }^{13} \mathrm{C}$-depleted OC [Arthur et al., 1988]. By definition the OAE2 is the main phase of enhanced carbon burial rates and, therefore, should be coeval with the interval of phases A and B of the carbon isotope excursion (see Kuypers et al. [2002] for review).

[16] The $\delta^{13} \mathrm{C}_{\text {org }}$ record for $\mathrm{S} 13$ has been published by Kuhnt et al. [1990]. In this study this record is complemented by new bulk isotopic data and previously unreported compound-specific $\delta^{13} \mathrm{C}$ values for sulphur-bound phytane $\left({ }^{13} \mathrm{C}_{\mathrm{Ph}}\right)$ at lower resolution. Sulphur-bound phytane is a diagenetic product of algal cholorophyll (see Kuypers et al. [2002] for a detailed discussion) and, therefore, the $\delta^{13} C_{\text {Phy }}$ record reflects variations in the isotopic composition of phytoplanktonic biomass at the time of deposition. $\delta^{13} \mathrm{C}_{\mathrm{org}}$ and $\delta^{13} \mathrm{C}_{\mathrm{Ph}}$ for $\mathrm{S} 57$ have been generated by Tsikos et al. [2004], and $\delta^{13} \mathrm{C}_{\mathrm{org}}$ for $\mathrm{S} 75$ by Kuhnt et al. [2001]; while the high-resolution $\delta^{13} \mathrm{C}_{\text {org }}$ record for $\mathrm{Mpl}$ has not been presented before (Figure 2).

[17] Despite a general consistent picture, the absolute values and trends of the $\delta^{13} \mathrm{C}_{\text {org }}$ records at the four investigated sites vary. In particular, the onset and end of phase $\mathrm{C}$ is not uniformly developed throughout the basin, which complicates the definition of the end of the OAE2 based on the bulk isotopic record. Additionally, there are some higher-frequency variations (Figure 3 ) at the four sites that could suggest variable and local contributions of terrestrial and marine OM. More likely, however, these variations document differences in the composition of the marine $\mathrm{OM}$ itself. Differences in bulk $\delta^{13} \mathrm{C}_{\mathrm{org}}$ may be related to different relative proportions of isotopically heavy and relatively light OM [van Kaam-Peters et al., 1998]. It has been shown, for example, that variations in the contribution of sulphurized carbohydrates to the sedimentary OM may account for changes in the isotopic composition of OC of up to $6 \%$ in black shales of the Kimmeridge Clay [van Kaam-Peters et al., 1998; Sinninghe Damsté et al., 1998]. Large variations in the degree of OM sulphurization have also been documented for the Tarfaya black shales [Kolonic et al., 2002] and thus could well account for the recorded high-frequency variations in bulk $\delta^{13} \mathrm{C}_{\mathrm{org}}$ especially in combination with temporal and spatial fluctuations in marine productivity.

\subsection{Definition of the OAE2 at Tarfaya}

[18] Despite some minor differences there is a good agreement between the isotopic and cyclostratigraphic records of sites S13, S57, S75 and Mpl (Figure 2). The isotope and cyclostratigraphy was therefore used in combination with new biostratigraphic data to redefine the stratigraphic extent of the OAE2 for the Tarfaya Basin. At Pueblo (Colorado, USA), the proposed global boundary stratotype section for the base of the Turonian [Kennedy et al., 2000], the end of the OAE2 $\left(\delta^{13} \mathrm{C}_{\text {org }}\right.$ phase $\mathrm{B} / \mathrm{C}$ boundary) falls at the $\mathrm{C} / \mathrm{T}$ boundary, as defined by the base of the Watinoceras devonense Ammonite zone [Kennedy et al., 2000] (Figure 2). An associated event is the first occurrence (FO) of Q. gartneri (nannofossil). These observations have been reproduced at Eastbourne (Sussex, England; Figure 2), where a much more detailed OAE2 $\delta^{13} \mathrm{C}_{\text {carb }}$ record is now available [Tsikos et al., 2004], together with ammonite [Gale et al., 1993] and nannofossil biostratigraphy. Unfortunately, the $W$. devonense Ammonite zone is not well constrained at Tarfaya [Kuhnt et al., 1997] and, therefore, can hardly be used as a convincing criterion to define the $\mathrm{C} / \mathrm{T}$ boundary. To overcome this limitation at Tarfaya and to provide a consistent stratigraphic pattern with the Pueblo and Eastbourne sections we used the FO of $Q$. gartneri to define the $\mathrm{C} / \mathrm{T}$ boundary and thus the end of the OAE2. Accordingly, the phase $\mathrm{B} / \mathrm{C}$ boundary at sites S13 (J. Mutterlose, personal communication, 2003) and S57 is located at the top of cycle 3 (Figure 2). Following this new integrated biostratigraphic-chemostratigraphic definition, cycle -1 corresponds to $\delta^{13} \mathrm{C}$ phase $\mathrm{A}$, cycles $0-3$ to phase $\mathrm{B}$, and cycles 4-10 to phase $\mathrm{C}$ (Figure 2). Hence the OAE2 $\left(\delta^{13} \mathrm{C}\right.$ phases $\mathrm{A}$ and $\left.\mathrm{B}\right)$ corresponds to cycles 1 to 3 .

[19] A much longer interval has previously been assigned to the OAE2 at Tarfaya. Kuhnt et al. [1997], for example suggested that the OAE2 approximately corresponds to cycles -1 to 10 . However, this placement of the end of OAE2 at the top of cycle 10 is based on a problematic correlation of the FO of the planktonic foraminifer $H$. helvetica with the base of the $W$. devonense Ammonite zone. Additionally, the $\mathrm{FO}$ of $H$. helvetica is extremely late with regard to other bioevents and the $\delta^{13} \mathrm{C}$ excursion at 




Figure 4. Linear sedimentation rates $(\mathrm{cm} / \mathrm{kyr})$ and bulk accumulation rates $\left(\mathrm{g} / \mathrm{m}^{2} \cdot \mathrm{yr}\right)$ for the investigated Tarfaya sites.

Tarfaya [Kuhnt et al., 1997]. Kuypers et al. [2002] included an interval corresponding to cycles 1 to 8 within the OAE2, based on compound-specific $\delta^{13} \mathrm{C}$ values. This assignment, however, is not supported by either biostratigraphy or the new, high-resolution $\delta^{13} \mathrm{C}_{\text {org }}$ records presented here, and may well be explained by the comparably low resolution of the molecular isotope data presented by Kuypers et al. [2002]. In fact, our new compound-specific $\delta^{13} \mathrm{C}$ curves for sulphur-bound phytane $\left(\delta^{13} \mathrm{C}_{\mathrm{Ph}}\right)$ for $\mathrm{S} 13$ and $\mathrm{S} 57$ are consistent with the new placement of the end of the OAE2 at the top of cycle 3 (Figure 2).

\subsection{Duration of the OAE2 at Tarfaya}

[20] Differences in the definition of the OAE2 as determined by the placement of start and end points in a respective section interval are important but contradictory issues in Cretaceous research that have resulted in a broad range of published estimates of its duration (estimates vary between 250 kyr [Arthur and Premoli Silva, 1982; Lamolda et al., 1994; Paul et al., 1994] and $700 \mathrm{kyr}$ [Arthur and Premoli Silva, 1982]). Figures based on radiometric dating
[Obradovich, 1993] are subject to large errors, while those based on cyclostratigraphy [Lamolda et al., 1994; Paul et al., 1994; Kuhnt et al., 1997; Caron et al., 1999; Prokoph et al., 2001] rely on correct identification of Milankovitch cycles and the absence of significant hiatuses. One often used figure is that of $\sim 500 \mathrm{kyr}$, based on radiometric dating in the US Western Interior [Obradovich, 1993].

[21] This and any of the other published numbers on the duration of the OAE2 lack a definitive radiometric time control at the appropriate (millennial) scale to constrain the OAE2. The available average ages with their relatively large errors (in the order of a few $100 \mathrm{kyr}$ ), therefore, should always be regarded as preliminary and subject to revision against independent new time models. Such independent models may come from cyclostratigraphic analysis of rhythmic CT strata [e.g., Kuhnt et al., 1997; Sageman et al., 1997; Meyers et al., 2001]. For example, evolutive harmonic analysis of cyclostratigraphic data series permits the identification of hiatuses, as well as changes in sedimentation rate, and allows for corrections [Meyers et al., 2001]. Application of this moving window Fourier tech- 

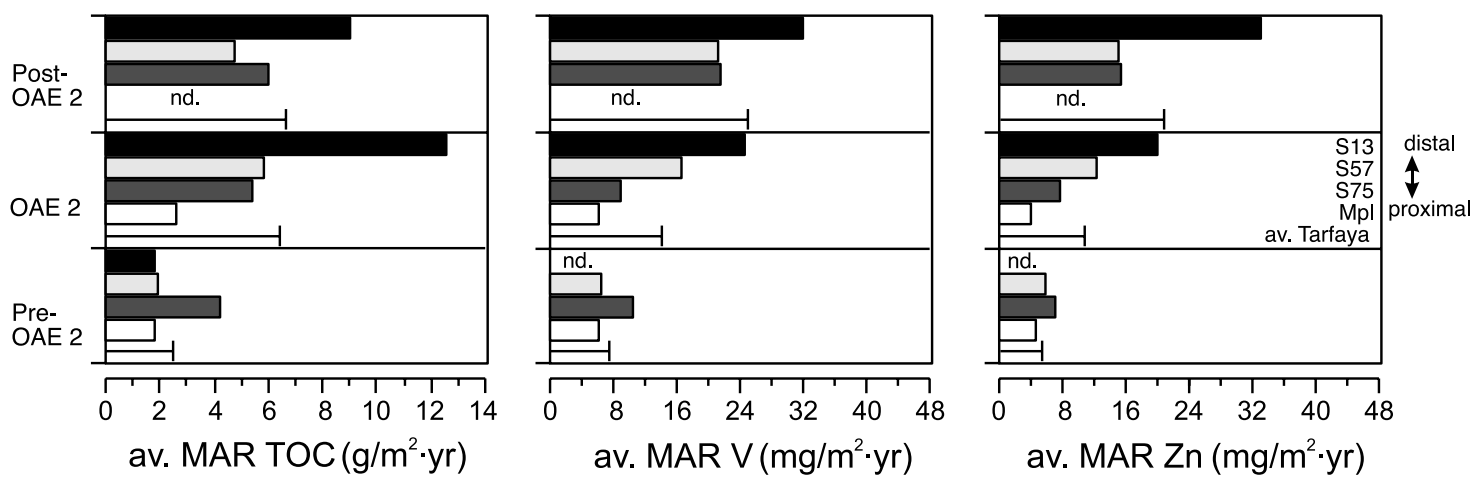

Figure 5. General trends of average accumulation rates of $\mathrm{OC}, \mathrm{V}$, and $\mathrm{Zn}$ across the Tarfaya core transect and separated according to their stratigraphic position relative to the OAE2 (S13, Black bar; S75, dark gray bar; S57, light gray bar; Mpl, white bar; Tarfaya Average, bold line). Pre-OAE2 corresponds to the interval predating cycle -1 , "OAE2" to cycles $-1-3$ (phases A and B), and "post-OAE2" to cycles 4-10 (phase C) (see also Figure 2). Note that for the post-OAE2 estimated average, Tarfaya values are based on three sites only because no data are available for Mpl. The same holds true for pre-OAE2 trace metal MARs where no data are available for S13. Since Mpl always has the lowest and S13 the highest values, comparison of the Tarfaya average values should be done with care.

nique to the Tarfaya $\mathrm{S} 13$ record supports a total duration of $\sim 490 \mathrm{kyr}$ for the $\delta^{13} \mathrm{C}$ phase A-B (cycles 1 through 3 ) [Meyers, 2003] here defined as the OAE2.

[22] In order to reconstruct controls on marine sedimentation during black shale formation in the Tarfaya Basin, we present geochemical data as mass accumulation rates (MARs) against age, applying our integrated time model that considers eccentricity as the dominant periodicity of the cycles (Figure 2). As any study in paleoceanography our approach bears a number of principle assumptions and simplifications. For example, we cannot rule out some minor cycle interference of other orbital frequencies (e.g., eccentricity superimposed by obliquity and precession). However, there is no simple and reliable way on the basis of our data to identify and filter such interferences. We also assume that sedimentation rates were constant during the deposition of the individual sedimentary couplets.

\section{Mechanisms of Black Shale Deposition in the Tarfaya Basin}

6.1. Variations in Carbon, Biomarker, and Trace Metal Contents

[23] Despite the vicinity to the African continent, the Tarfaya Basin did not receive a significant terrestrial contribution during the OAE2. This is clearly indicated by the extremely low abundance of metals of terrestrial origin like $\mathrm{Zr}(\sim 0.004 \%), \mathrm{Al}(\sim 1 \%)$ and $\mathrm{Ti}(\sim 0.07 \%)$ throughout the depth-transect studied. Instead, linear sedimentation rates (SRs in $\mathrm{cm} / \mathrm{kyr}$ ) and mass accumulation rates (MARs in weight-unit $/ \mathrm{m}^{2} \cdot \mathrm{yr}$ ) of the bulk sediments are primarily controlled by biogenic carbonate/silica deposition. The significance of biogenic carbonate and silica as the most important components of the sediments is shown by the fact that the investigated samples plot slightly below the trend line connecting the carbonate and the average shale endmembers (Figure 3). We concede, however, that it is almost impossible to quantify biogenic silica using chemical methods, due to almost complete recrystallization into opal-CT. Hence the variations in $\mathrm{OC}$, trace metal and biomarker abundances are expressed as MAR to obtain records that are independent of cyclic variations in carbonate/silica flux.

\subsection{Linear Sedimentation and Mass Accumulation Rates}

[24] On average, SRs are moderate to high, on the order of about $1.6 \mathrm{~cm} / \mathrm{kyr}$ at Mpl, $2.4 \mathrm{~cm} / \mathrm{kyr}$ at S57 and S75, and up to $4.8 \mathrm{~cm} / \mathrm{kyr}$ at S13 (Figure 4). They more than double over the stratigraphic interval and generally approach highest values at the transition from OAE2 phase B to phase C (cycles 3 and 4), and decrease gradually within phase $C$ (Figure 4). Also, SRs are often elevated in odd-numbered cycles. Small variations in this general pattern along the site transect are most likely attributable to local effects of topography, ocean currents, sediment grain size, and/or productivity. The general pattern, however, indicates the presence of a lower-frequency rhythm being superimposed on the well-developed bedding cycles. At S13, one such low-frequency cycle may cover between 8 and 11 highfrequency bedding couplets (Figure 4). The MARs are highest in cycles 1 to 8 covering the OAE2 (phases A and $\mathrm{B}$ ) and the beginning of phase C. Maximum MARs of up to $200 \mathrm{~g} / \mathrm{m}^{2}$. yr occur at the most distal Site S13. Averaged values of about $160,60,80$ and $40 \mathrm{~g} / \mathrm{m}^{2}$. yr for S13, S57, $\mathrm{S} 75$ and $\mathrm{Mpl}$, respectively, indicate a distinct trend of decreasing MARs from the basin center to the more proximal sites.

\subsection{Variations in Organic Carbon Mass Accumulation Rates}

[25] Average OC accumulation rates (OC MAR) for the Tarfaya Basin (Figure 5) increase from $\sim 2 \mathrm{~g} / \mathrm{m}^{2}$. yr before the OAE2 to $\sim 6 \mathrm{~g} / \mathrm{m}^{2} \cdot \mathrm{yr}$ during the OAE2 and remain high during post-OAE phase $\mathrm{C}\left(\sim 7 \mathrm{~g} / \mathrm{m}^{2} \cdot \mathrm{yr}\right)$. This general 


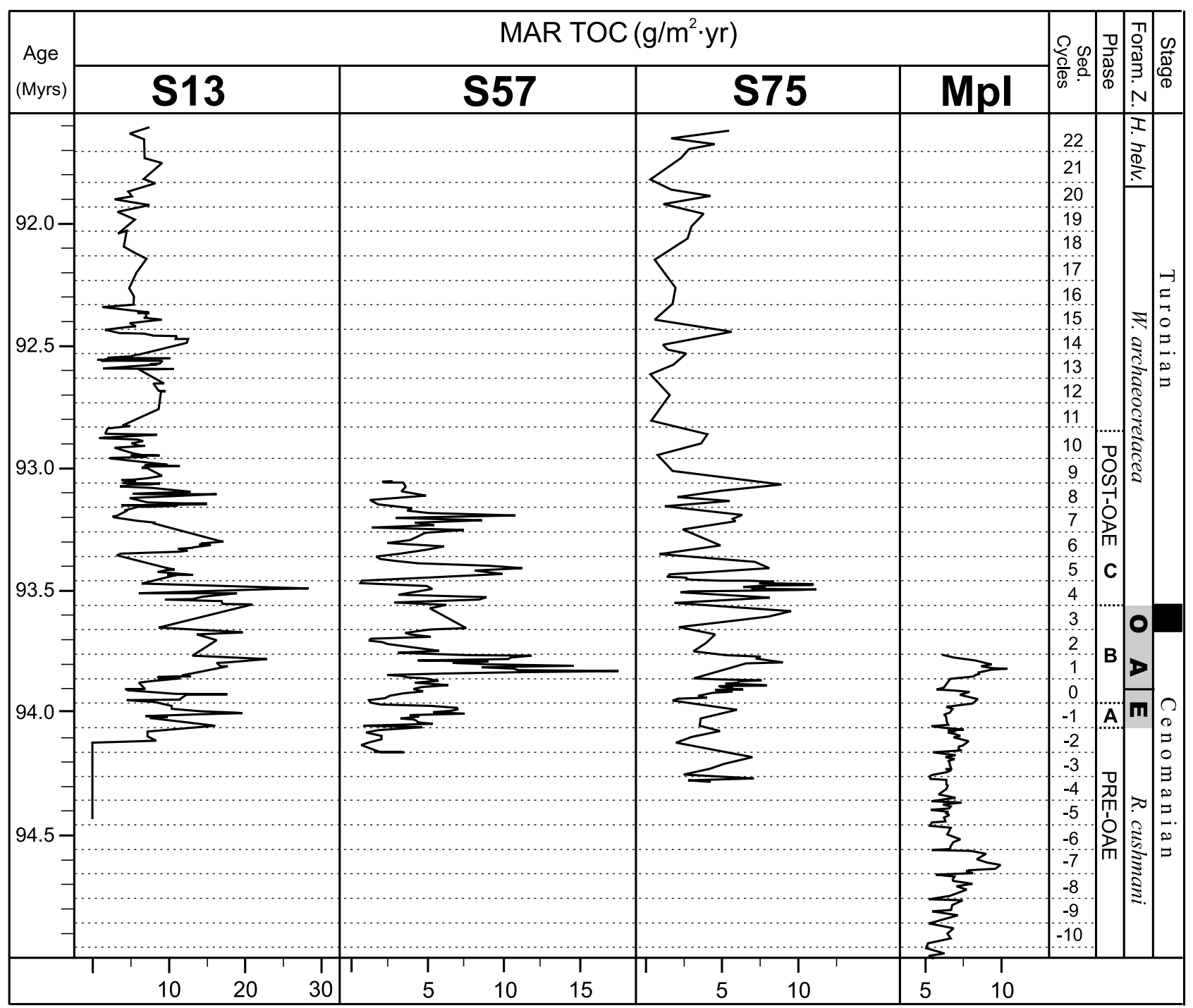

Figure 6. Organic carbon mass accumulation rates $\left(\mathrm{g} / \mathrm{m}^{2} \cdot \mathrm{yr}\right)$ for the investigated Tarfaya sites.

pattern is most pronounced in the basin center at S13, where average MAR OC increases by a factor of six from $\sim 2 \mathrm{~g} / \mathrm{m}^{2} \cdot$ yr prior to the OAE2 to $\sim 12 \mathrm{~g} / \mathrm{m}^{2} \cdot$ yr during the OAE2. This distinct increase is followed by a moderate decrease during post-OAE phase $\mathrm{C}$ down to $\sim 10 \mathrm{~g} / \mathrm{m}^{2} \cdot \mathrm{yr}$. A similar, although less pronounced trend is observed for the transitional Sites S57 and S75 (for Mpl no data is available for phase C). Average OC MAR at the transitional Sites S57 and S75 are two to four times lower than those at Site S13 in the basin center (Figure 5). At Site S75, the average trend differs from the other records by its relatively high OC MAR for the period predating the OAE2. Opposite to the other sites, there is only a moderate increase in average $O C M A R$ from $\sim 4 \mathrm{~g} / \mathrm{m}^{2}$. yr during the pre-OAE2 to $\sim 5 \mathrm{~g} / \mathrm{m}^{2} \cdot \mathrm{yr}$ during OAE2 at Site S75. At Site Mpl, average OC MAR also exhibit a moderate increase from pre-OAE2 $\sim 1.7 \mathrm{~g} / \mathrm{m}^{2} \cdot$ yr to OAE2 times $\sim 2.5 \mathrm{~g} / \mathrm{m}^{2} \cdot \mathrm{yr}$.

[26] Superimposed on the long-term trend are distinct higher-frequency and high-amplitude fluctuations in $\mathrm{OC}$
MAR (Figure 6). These amplitudes are generally higher in the central part of the basin (S13, S57 and S75) compared to the proximal $\mathrm{Mpl}$, and often synchronous (e.g., in cycles $-1,1$, and 3/4). The extreme differences between baseline and maximum values approach $\sim 16 \mathrm{~g} / \mathrm{m}^{2} \cdot \mathrm{yr}\left(\sim 2 \mathrm{~g} / \mathrm{m}^{2} \cdot \mathrm{yr}\right.$ baseline, $14-18 \mathrm{~g} / \mathrm{m}^{2}$. yr maximum) at Sites S57 and S75. They even increase up to $28 \mathrm{~g} / \mathrm{m}^{2} \cdot \mathrm{yr}\left(\sim 2-4 \mathrm{~g} / \mathrm{m}^{2} \cdot \mathrm{yr}\right.$ baseline, $30 \mathrm{~g} / \mathrm{m}^{2}$. yr maximum) at $\mathrm{S} 13$ revealing widespread, large and short-term fluctuations in OC MAR. At the proximal Mpl, OC MAR is consistently lower, both in minimum and maximum values, ranging from baseline values below $1 \mathrm{~g} / \mathrm{m}^{2} \cdot \mathrm{yr}$ as high as $5 \mathrm{~g} / \mathrm{m}^{2} \cdot \mathrm{yr}$ (maximum amplitude $5.5 \mathrm{~g} / \mathrm{m}^{2}$. yr, for comparison). Baseline, maximum, and average MARs clearly identify the basin center as the primary site of OC burial. Given the different time resolution, stratigraphic range, and cyclostratigraphic uncertainty of the study sites, peak accumulation of OC was centered on cycles -7 (pre-OAE) and 1 (phase B) near the paleocoastline. In the deeper part of the basin, highest 


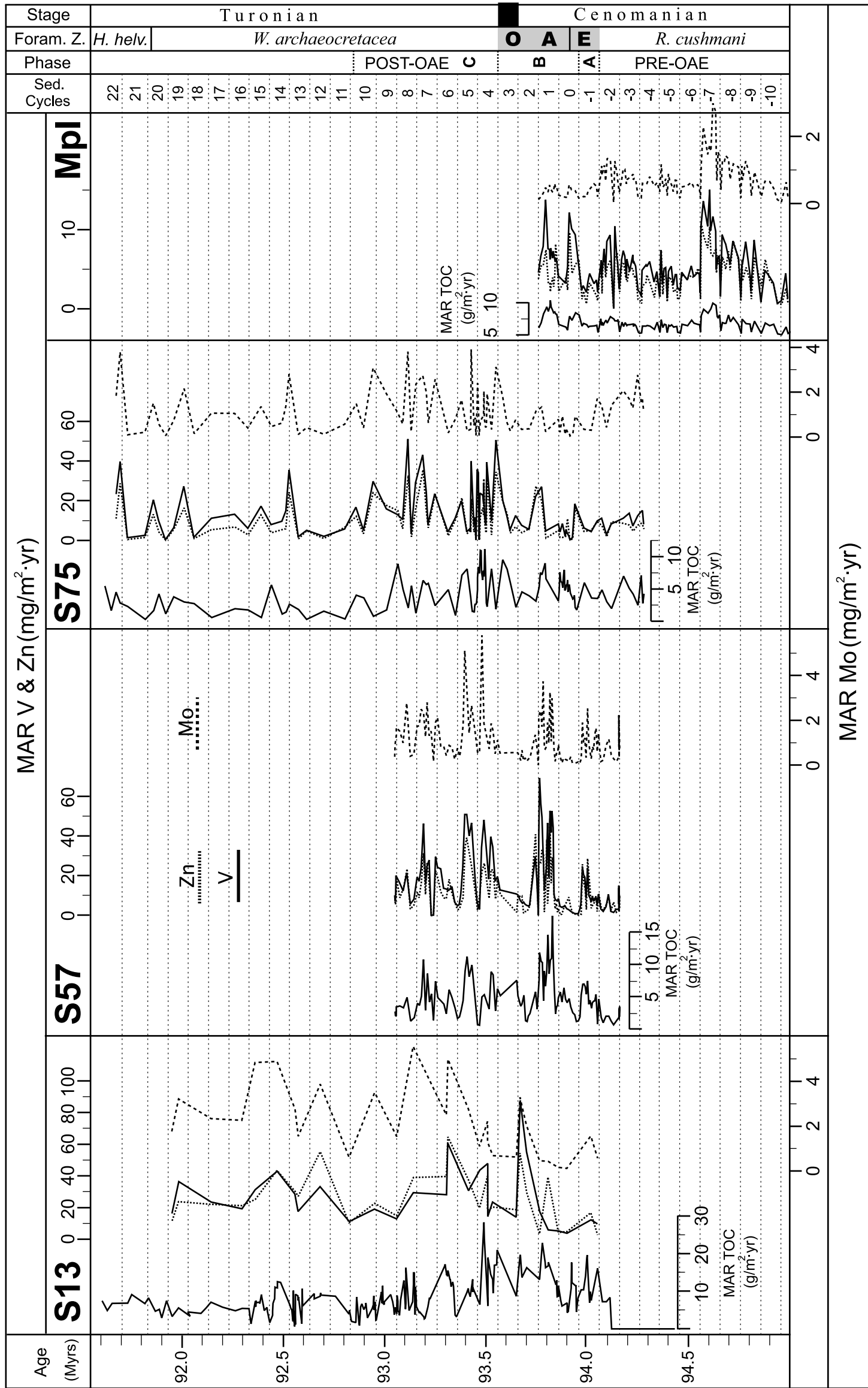

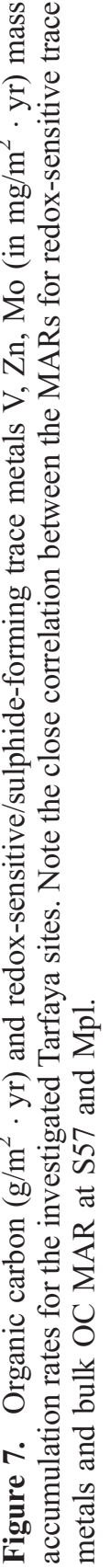


accumulation of OC was restricted to cycles -1 (phase A) through 8 (phase $\mathrm{C}$ ), approaching maximum values during cycles 1 (at all sites) and the upper part of cycle 3 (end of phase B, S75) through the lower part of cycle 5 (lower part of phase C, S13 and S57) (Figure 6). These periods of maximum OC accumulation are obviously structured by bundles of three to five individual peaks, best documented in cycle 1 at S57 and in cycle 8 at S13 (Figure 6), but also recognizable at the other sites. These bundles cover about one sedimentary cycle, which, given their assigned duration of $\sim 100 \mathrm{kyr}$, likely reflect precessional or millennial-scale ( $\sim 5-7 \mathrm{kyr})$ fluctuations in OC MAR. The identification of precessional- or higher-frequency forcing in the geological record, of course is restricted to a few sedimentary cycles where data resolution is sufficiently high. Sub-Milankovitch forcing with a wavelength of approximately $20-30 \mathrm{~cm}$ (corresponding to about 3-4 kyr) has been identified in the TOC profile of cycle 0 at Site 75 [Kuhnt et al., 2001]. A similar frequency is recognized in mm-scale XRF scanning profiles of Sites S57 and S75 and power spectra obtained from high-resolution gray scale data of the complete S75 section [Kuhnt et al., 2004]. The presence and consistency of this high-frequency variability in $O C M A R$ strongly supports a close link to climate forcing. Sedimentation in the Tarfaya Basin, however, did not react in a strictly uniform manner to these short-term climate variations as evident from local patterns that differ in detail between the proximal to distal study sites.

\subsection{Bottom Water Anoxia}

[27] The repetitive deposition of laminated OC-rich sediments throughout the investigated sections and the low abundances of benthic foraminifera especially in the interval representing OAE2 phases A through C at S75 [Luderer, 1999; Kuhnt et al., 2004] already indicate predominantly suboxic to anoxic bottom water conditions in the Tarfaya Basin. However, the occurrence of thin $(10-20 \mathrm{~cm})$, bioturbated and carbonate-rich layers within the black shale beds suggests periodic occurrence of more oxic bottom waters in the order of about $20 \mathrm{kyr}$ based on the linear sedimentation rates. Additional information on bottom water redox conditions may be derived from chalcophilic elements (e.g., Mo and $\mathrm{Zn}$ ) that precipitate as sulphides under euxinic conditions and certain redox sensitive elements (e.g., Mo and V) that are immobilized under reducing conditions [Jones and Manning, 1994; Nijenhuis and De Lange, 2000]. In accordance with the extraordinary enrichment of these metals in many $\mathrm{C} / \mathrm{T}$ black shales from the deep proto-N Atlantic it has been proposed that the precipitation of trace metals derived from an expanded euxinic water column during the OAE2 [e.g., Brumsack, 1980, 1986; Thurow et al., 1988; Sinninghe Damsté and Köster, 1998; Kuypers et al., 2002]. The new high-resolution trace metals profiles from the Tarfaya Basin transect provide key information that confirm a temporal coupling of the midCretaceous northwest African Shelf to the euxinic N Atlantic deep and intermediate waters. Furthermore they indicate a distinct covariation between black shale formation (peak OC burial) and trace metal enrichment on short (millennial) timescales, i.e., on an individual sample-by-sample basis.
Apart from a limited number of recent millennium-scale studies on other Cretaceous black shale sections (e.g., the OAE3 in the tropical equatorial Atlantic at ODP Site 959 [Beckmann et al., 2004]), similar relationships so far have only been documented for longer-term and lower-resolution data series [e.g., Jones and Manning, 1994; Algeo and Maynard, 2004].

[28] On average, Tarfaya black shales are significantly enriched in redox-sensitive and sulphide-forming trace metals relative to "average shale" [Wedepohl, 1991] with enrichment factors of $\sim 140$ for Mo and $\sim 23$ for $\mathrm{V}$ and $\mathrm{Zn}$ [see also Lüning and Kolonic, 2003]. These trace metal properties are comparable to those reported from deep-sea OAE2 black shales [e.g., Brumsack, 1980, 1986; Thurow et al., 1988; Arthur et al., 1990; Kuypers et al., 2002]. The highest enrichment in redox-sensitive and/or sulphide-forming trace metals at Tarfaya is observed during OAE2 phases A through $\mathrm{C}$ (Figure 5). Although not as pronounced as for OC MAR, there is a distinct spatial and temporal shift in MARs of trace metals, with highest values in the basin center. Tarfaya average MARs for $\mathrm{V}$ and $\mathrm{Zn}$ almost double from pre-OAE2 values of $\sim 7 \mathrm{mg} / \mathrm{m}^{2} \cdot \mathrm{yr}$ and $\sim 6 \mathrm{mg} / \mathrm{m}^{2} \cdot \mathrm{yr}$, respectively, to OAE2 values of $\sim 13 \mathrm{mg} / \mathrm{m}^{2}$. yr and $\sim 11$ $\mathrm{mg} / \mathrm{m}^{2} \cdot \mathrm{yr}$, respectively, and further increase by a factor of two to maximum values of $\sim 24 \mathrm{mg} / \mathrm{m}^{2}$. yr and $\sim 21 \mathrm{mg} / \mathrm{m}^{2}$ - yr, respectively, for post-OAE2 phase C (Figure 5). The latter observation confirms that the northwest African Shelf was a primary site of anoxia throughout the entire $\mathrm{C} / \mathrm{T}$ transition and thus was not strictly confined to the OAE2. On an average basis, trace metal accumulation was highest at S13 during phases B and C with MARs for V and Zn up to twice as high as those calculated for the other sites (Figure 5). Different to OC MAR, the average trace metal MAR record of $\mathrm{S} 75$ remains relatively constant from preOAE2 to OAE2 times (Figure 5). Mpl exhibits lowest trace metal MAR values across the depth transect and, comparable to S75, does not reveal an increase from pre-OAE2 to OAE2 times (Figure 5).

[29] These long-term trends are modulated by higherfrequency and high-amplitude fluctuations in MARs of trace elements, often parallel and synchronous to $\mathrm{OC}$ MAR (Figure 7). The amplitudes exhibit extreme differences between baseline and maximum values, revealing drastic and short-term fluctuations in trace element MAR. The highest amplitudes between baseline and maximum values are most pronounced at S57 within phase B, where $\mathrm{Zn}$ exceeds $8 \mathrm{mg} / \mathrm{m}^{2}$. yr, Mo approaches $64 \mathrm{mg} / \mathrm{m}^{2} \cdot \mathrm{yr}$, and $\mathrm{V}$ is $48 \mathrm{mg} / \mathrm{m}^{2}$. yr at the top of cycle 1 and the lowermost phase C. At the adjacent Site S75, this general pattern remains comparable although highest amplitude variations are observed at the transition from phase B to $\mathrm{C}$ (cycles 3/4). At the proximal $\mathrm{Mpl}$ the amplitudes and extreme values, however, are lower, and approach levels below $3 \mathrm{mg} / \mathrm{m}^{2} \cdot \mathrm{yr}, 16 \mathrm{mg} / \mathrm{m}^{2} \cdot \mathrm{yr}$, and $25(10) \mathrm{mg} / \mathrm{m}^{2} \cdot \mathrm{yr}$ for Mo, V, and $\mathrm{Zn}$, respectively (Figure 7).

[30] Despite scattering, there is an obvious positive correlation between MARs of Mo, V, and $\mathrm{Zn}$ and OC MAR on a sample-by-sample basis, at least for Sites S57 and Mpl (Figure 7) where sample resolution is the highest and most regular over the whole profile and where geochemical 


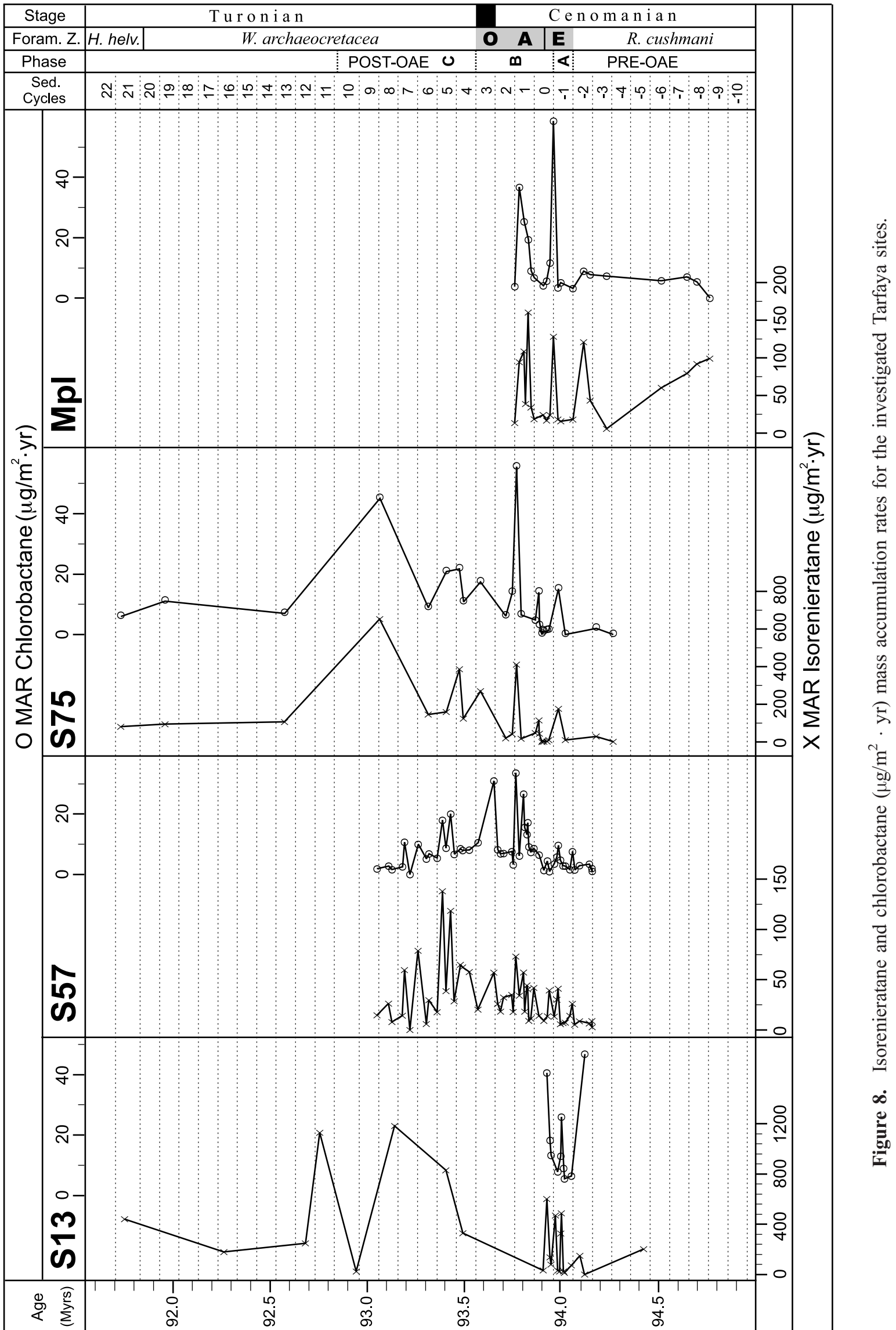


analyses were carried out on exactly the same homogenized sample material. Furthermore, data from these two sites represent $\mathrm{cm}$-scale sample intervals, whereas samples from S75 and S13 integrate over $\sim 10 \mathrm{~cm}$ intervals (except for cycles 0 and 4 at S75, where a high-resolution re-sampling had been performed [Kuhnt et al., 2001]. Therefore the integration of different subsamples hampers direct comparison of the two data sets and, to some extent, probably also explains the few inconsistencies (noncorrelation) between OC MAR and MARs in trace metals observed at S13 and S75 (e.g., cycles 8, 11, and 15 at S13 and cycles $-3,1,5$ through 7 at S75; Figure 7). The consistent relationship at S57 and Mpl, however, strongly supports the conclusion that variations in bottom water oxygenation were rapid and synchronous with $\mathrm{OC}$ burial at millennial timescales and thus should have had a distinct impact on the preservation of OM, with anoxic conditions leading to enhanced preservation of OM. Following that conclusion the new highresolution data from the Tarfaya transect indicate drastic and short-term fluctuations in bottom water oxygen levels. On the basis of the extreme differences in OC MAR and MARs of trace metals in adjacent samples, the transition time between better oxygenated and severely oxygen-depleted bottom water conditions can roughly be estimated. Despite limitations, the present data confirm repetitive fluctuations in the redox state of the bottom waters at Milankovitch and probably even shorter timescales. Both frequencies strongly implicate a close link to climate forcing.

\subsection{Photic Zone Euxina}

[31] To further investigate whether anoxic or euxinic redox conditions at least temporarily extended into the photic zone, a subset of samples was analyzed for fossil derivatives of specific carotenoid pigments, isorenieratene and chlorobactene [Koopmans et al., 1996]. Both carotenoids are exclusively biosynthesized by the brown and green colored strain of green sulphur bacteria Chlorobiaceae, respectively [e.g., Madigan et al., 2000]. As strict anaerobes, these bacteria require both light and free hydrogen sulphide in the water column (euxinic conditions) in order to be able to perform photosynthesisis. At present, these conditions are restricted to a few isolated marine basins, such as the Black Sea, where Chlorobiaceae thrive near the sulphide/oxygen interface at light levels of less than $1 \%$ (or $<0.5 \mu \mathrm{E}$ ) of surface irradiance [van Gemerden and Mas, 1995; Repeta et al., 1989]. The green strain requires higher light intensity and, therefore, thrives at shallower depths ( $\sim 15 \mathrm{~m}$ water depth) than the brown strain $(\sim 30-$ $150 \mathrm{~m}$ water depth). Assessing the presence and accumulation of these two biomarkers may thus be used to deduce the position of the chemocline and its variability within the photic zone. In addition, isorenieratane and chlorobactane are very labile organic compounds that rarely survive longdistance transport, and consequently are indicators of a local (autochthonous) marine source [Sinninghe Damsté et al., 2001], especially in case of the shallow ( $400 \mathrm{~m})$ Tarfaya Basin.

[32] Isorenieratane and chlorobactane were detected at all sites and at all stratigraphic levels, although at different MARs and at high temporal variability (Figure 8). For isorenieratane, highest MARs of up to $1200 \mu \mathrm{g} / \mathrm{m}^{2} \cdot \mathrm{yr}$ are observed in cycles 8 (post-OAE phase C) and 11 (above the OAE2) in the basin center at S13, which is in agreement with a similar observation for trace element MARs as stated above. The corresponding MARs of isorenieratane strongly decrease toward the transitional sites S57 (below $140 \mathrm{\mu g} / \mathrm{m}^{2} \cdot \mathrm{yr}$, for explanation see comments in the next paragraph) and $\mathrm{S} 75$ (below $600 \mu \mathrm{g} / \mathrm{m}^{2} \cdot \mathrm{yr}$ ), and reach lowest values at the proximal $\mathrm{Mpl}\left(200 \mu \mathrm{g} / \mathrm{m}^{2}\right.$. yr). Maximum MARs of isorenieratane in the Tarfaya transect are similar to those reported from DSDP Site 367 $\left(\sim 2600 \mu \mathrm{g} / \mathrm{m}^{2} \cdot \mathrm{yr}\right)$, but exceed those at DSDP Site 603 in the NE Atlantic [Kuypers et al., 2002] by a factor of $\sim 200$. The gradual decline in MARs of isorenieratane toward the paleocoastline is not followed by MARs of chlorobactane (Figure 8). Instead, MARs for chlorobactane remain in the same range across the transect with maximum values exceeding $\sim 32 \mu \mathrm{g} / \mathrm{m}^{2}$. yr between cycles -1 and 0 (the transition from OAE phases A to $\mathrm{B} ; \mathrm{S} 13$ and $\mathrm{Mpl}$ ), in the upper part of cycle 1 (central part of OAE phase B; S57, 75 and $\mathrm{Mpl}$ ), and in the lowermost part of cycle 3 (end of OAE phase B; S57) (Figure 8). The synchrony of maxima in MARs of chlorobactane and isorenieratane indicate intervals with an extremely shallow chemocline in the photic zone and thus euxinic redox conditions. Given the lower time resolution of the biomarker records compared to the bulk geochemical records (with the exception of S57), basin-wide synchrony of photic zone euxinia can only be claimed for cycles -1 and 1 , although it appears reasonable to expect that other periods of basin-wide and synchronous peak OC accumulation represent comparable extreme redox conditions. Notably, the enrichment of biomarkers is not restricted to OAE2 phases A and B, as would be expected from the global carbon isotopic excursion assuming that the shift in isotopic signatures is a direct record of maximum OC burial and anoxia/euxinia [Kuypers et al., 2002]. Instead, maximum MARs of isorenieratane and chlorobactane are not only recorded within, but also well after the OAE2 suggesting that euxinic conditions prevailed well beyond the OAE2 phase $\mathrm{C}$ at Tarfaya. This observation further supports the conclusion that the Tarfaya Basin has been a preconditioned area where the establishment of extreme redox conditions was not strictly confined to the OAE2.

[33] MARs of isorenieratane are about one order of magnitude lower at S57 than those from the adjacent S75 (Figure 8). This distinct difference is difficult to reconcile with the consistent pattern of other geochemical data from these two sites, and therefore could relate to the different analytical procedures applied to isolate the biomarkers. At S57, quantification was performed on the polar subfraction of the total extract whereas total extracts were used at the other sites. It is likely that this procedure resulted in the generally lower biomarker yields from the polar subfractions when compared to the total extract data from a similar setting. Despite the lower MARs there is a consistent and often parallel trend of the S57 biomarker data with those from the other profiles, e.g., at the transition from cycles -1 to 0 (S57 to S13) or at the top of cycle 1 (S57 to S75) (Figure 8). We believe that this consistency allows confidence in the quality of the S57 biomarker record, which can 
thus be used as a reference profile for short-term variability of photic zone euxinia. This is of relevance since the time resolution of the S57 biomarker record to our knowledge is unique for OAE2 black shales, and thus bears an exceptional potential for assessing fluctuations in photic zone euxinia at orbital timescales and discussing the linkage to bottom water anoxia and OC burial. Synchronous to OC MAR and MARs of trace metals, MARs of biomarkers reveal short-term and high amplitude fluctuations. Peak-to-peak correlation at S57, for example, shows that biomarker maxima exactly match maxima in OC except for a few samples where OC value are at transitional levels (e.g., in the central part of cycle 7 and at the top of cycle 6; Figure 8). This positive correlation with OC burial strongly supports a direct and likely causal link between bottom water and photic zone redox conditions. The repetitive alternation of maxima and minima in MARs of all three parameters and their spatiotemporal pattern indicate a highly variable oxygen/sulphide boundary that was not uniformly developed over the entire shelf basin. The data instead propose a shallow chemocline well within the upper photic zone during peak OC burial that deepened (probably to the lower part of the photic zone) during reduced OC burial and migrated downward to pore waters of the sedimentary column during deposition of the decimeter-scale limestone interlayers.

\subsection{Depositional Model}

[34] The investigated Tarfaya sites reveal extremely high MARs of OC, trace metals and photic zone euxinia biomarkers. It has been shown that high-amplitude and shortterm variations generally occurred synchronously for all parameters on a sample-by-sample basis and across the core transect. The principle mechanisms responsible for these distinct patterns probably combine marine productivity followed by stratification-driven anoxia. Furthermore, OC burial and black shale formation must have been intimately linked to nutrient cycling processes. The strongly reduced and generally constant supply of minerals from continental sources excludes continental runoff as a primary mechanism controlling nutrient supply and thus black shale formation. This conclusion may not be expected from the geological context, considering the vicinity of the shelf basin to the African continent and the extremely warm global climate during the mid-Cretaceous, which should have stimulated an intensified hydrological cycle [Huber et al., 2002] with high precipitation and runoff from dense subtropical vegetation at low latitudes [e.g., DeConto et al., 1999]. The reason for the depressed continental signature in the sedimentary record at Tarfaya remains enigmatic at present and requires further investigation. It may be speculated, however, that most of the continental matter exported during more humid time intervals, if it was supplied at all, either bypassed the study sites via small-scale channels in front of fossil river mouths or was trapped in lagoons or large-scale lakes near the river mouth or within the estuaries, comparable to the modern tropical African Comoe or Congo Rivers.

[35] More probably, wind-induced continental upwelling of nutrient-rich and severely oxygen-depleted (or even euxinic) intermediate waters from the deep Atlantic was the primary mechanism that determined marine sedimenta- tion on the mid-Cretaceous northwest African Shelf. Following that model, periods of enhanced (trade) wind intensity should have fostered the establishment of anoxia/ euxinia and black shale formation along the northwest African Shelf through both enhanced marine productivity and inflow of oxygen-depleted intermediate waters. Weakening of the trade winds on the other hand should have resulted in reduced upwelling and thus partial re-establishment of oxic conditions in the water column. From a modern perspective such a situation would correspond to insolation-driven alternations of more arid and humid conditions on the African continent during the $\mathrm{C} / \mathrm{T}$ with strong trades at a southern position of the Intertropical Convergence Zone (ITCZ) representing arid periods and weak trades at a northern position of the ITCZ during humid intervals. Modeling of global climate and precipitation across the $\mathrm{C} / \mathrm{T}$ transition supports the presence of such insolation-driven fluctuations in aridity and humidity over low-latitude W Africa and S America [Flögel, 2002]. The consistency of conclusions deduced from the geological record with implications from modeling suggests that $\mathrm{OC}$ burial at Tarfaya was intimately linked to atmospheric circulation dynamics, similar to its Quaternary analogue [e.g., Tiedemann et al., 1994].

[36] Since photic zone euxinia represents the most extreme and therefore most unstable oceanographic condition during the $\mathrm{C} / \mathrm{T}$, it should have been vulnerable to wind-induced mixing of surface waters on the paleoshelf. Short-term and repetitive admixture of oxygen to surface waters is a common feature of modern low-latitude marine sedimentation [e.g., Ittekkot et al., 1992], the primary agent being seasonal changes in wind stress. Considering the higher-resolution biomarker records from S13 (cycle - 1) and S57, short-term (seasonal to decadal) fluctuations in surface water mixing may be inferred. The repetitive and short-term breakdown of the chemocline, however, may have required the interaction of a variety of processes. Among others they may suggest wind-induced (seasonal?) depression of the mixed layer down to the seafloor (a process that is not considered likely, at least not for the basin center given an estimated maximum water depth of about $400 \mathrm{~m}$ ), periodic advance and retreat of severely oxygen-depleted intermediate waters from the adjacent Atlantic ocean combined with Eckmann pumping of these nutrient-rich and oxygen-depleted intermediate waters to the photic zone (a more reasonable scenario), or a mixture of both processes (the most probable scenario). The pacing and duration of such a midwater advance and retreat and thus upward migration of nutrients and anoxia to the photic zone can hardly be assessed based on the present data; however, this mechanism should have been primarily confined to the OAE2 itself. Furthermore, this process may have operated on a longer timescale (millennial to orbital?) compared to the buildup or break-down of photic zone euxinia which was likely to have been more of a seasonal or interannual oceanographic feature. Given the high-resolution biomarker patterns in cycle -1 at S13 and in cycle 1 at S57 (Figure 8), break-down of the photic zone euxinia occurred at least four times within one sedimentary cycle, synchronous to a decline in $\mathrm{OC}$ and trace metal accumulation. This synchrony and pacing evidence a close interaction of photic zone and 
bottom water oxygenation and propose that the repetitive shoaling of the chemocline significantly fostered enhanced OM preservation in a highly dynamic depositional system.

[37] To address the important and often contradictory issue of whether productivity or preservation was the primary control determining $\mathrm{OC}$ burial during black shale formation, we consider two principal variables, the preservation factor and export productivity. Assuming average properties for both variables from modern marine highproductive areas, i.e., $\sim 300 \mathrm{gC} / \mathrm{m}^{2}$. yr for export productivity and a preservation factor of $1 \%$ [Suess, 1980], OC accumulation in the Tarfaya Basin should have been less than $\sim 3 \mathrm{gC} / \mathrm{m}^{2}$. yr. The calculated maximum average OC $M A R$ during the OAE2, instead, has been estimated to be between $\sim 4 \mathrm{gC} / \mathrm{m}^{2} \cdot \mathrm{yr}$ and $13 \mathrm{gC} / \mathrm{m}^{2} \cdot \mathrm{yr}$ in the central part of the basin. If marine productivity was the only factor controlling OC burial on the Tarfaya Shelf, an unrealistic export productivity in the order of 400 to $1200 \mathrm{gC} / \mathrm{m}^{2} \cdot \mathrm{yr}$ or more has to be proposed for the mid-Cretaceous northwest African continental margin. We therefore conclude that preservation of OM was considerably enhanced compared to modern marine upwelling systems. Consistent with this, very high hydrogen indices $550-850 \mathrm{mgHC} / \mathrm{gTOC}$ and the abundance of sulphur-bound compounds are indeed indicative for high preservation factors [Kolonic et al., 2002]. Increasing the preservation factor to $\sim 5 \%$, an average value determined for the modern Black Sea [Arthur et al., 1994; Sinninghe Damsté and Köster, 1998], results in an export productivity in the order of $\sim 200 \mathrm{gC} / \mathrm{m}^{2} \cdot \mathrm{yr}$ for the OAE2 in the Tarfaya Basin. However, given an estimated maximum water depth in the Tarfaya Basin center of about $400 \mathrm{~m}$, much of the OC flux can be related to rapid mass sinking, thus implying that preservation may have even been higher than the 5\%. Apparently, if we assume a very high preservation factor of $\sim 15 \%$ (as reported for the euxinic shallow water column of the Saanich Inlet [Sinninghe Damsté and Köster, 1998]) to our data, an export productivity between 40 to $100 \mathrm{gC} / \mathrm{m}^{2} \cdot \mathrm{yr}$ is required to account for the estimated OC accumulation at Tarfaya. Although the budget calculation herein is tentative, it strongly suggests that across the $\mathrm{C} / \mathrm{T}$ transition (and not necessarily the OAE2 itself) essentially both, increased production as well as preservation played a crucial role in the deposition of these oil prone source rocks.

\subsection{Global Impact of OC Burial on the Northwest African Shelf During the OAE2}

[38] Globally enhanced OC burial associated with the OAE2 is considered a primary mechanism that caused drawdown of $\mathrm{CO}_{2}$ from the atmosphere and consequently induced global cooling during the mid-Cretaceous [Arthur et al., 1988; Kuypers et al., 1999, 2002]. The widespread removal of reduced carbon during the OAE2 may also have strongly increased the oxygen concentration in the atmosphere, thus stimulating enhanced air pressure and temperature in the lower atmosphere [e.g., Ohkouchi et al., 1999]. One major sink for reduced carbon across the $\mathrm{C} / \mathrm{T}$ has been identified as the deep southern proto-N Atlantic [e.g., Kuypers et al., 2002]. In view of the exceptionally thick and OC-rich black shales in the Tarfaya area as part of the larger LaAaiun Basin (Figure 1), the question arises as to what extent the northwest African Shelf was responsible for the global OC burial associated with the OAE2. Once again, we want to emphasize that the northwest African Shelf in general has been preconditioned to be a primary site of $\mathrm{OC}$ burial, before and after the OAE2.

[39] To provide a first-order approximation a simple budget calculation was applied that roughly estimates the magnitude of OC burial in the Tarfaya Basin during the $\mathrm{C} / \mathrm{T}$ transition. In this budget calculation (I) an average Tarfaya OC MAR of $\sim 2.5 \mathrm{gC} / \mathrm{m}^{2}$. yr for the period predating the OAE2 and (II) $\sim 6.5 \mathrm{gC} / \mathrm{m}^{2} \cdot \mathrm{yr}$ for the OAE2 (numbers representing the Tarfaya average values as displayed in Figure 5), as well as (III) a gross total onshore and offshore area of $\sim 170,000 \mathrm{~km}^{2}$ for the entire Tarfaya-LaAaiun Basin [Leine, 1986] is considered. The resulting overall excess OC burial in the Tarfaya-LaAaiun Basin is equivalent to $\sim 6$. $10^{10}$ mols $\mathrm{C}$ per year, or, when extrapolated to the time period assumed for the OAE2 (i.e., $\sim 500 \mathrm{ka}$ ), $\sim 2.8 \cdot 10^{16}$ mols $\mathrm{C}$, respectively. The dimension of these numbers becomes apparent when they are compared to the overall global excess OC burial as proposed by Arthur et al. [1988] for the OAE2. Arthur et al. [1988] calculated a global excess OC burial above the $\mathrm{C} / \mathrm{T}$ background in the order of $\sim 1.6 \cdot 10^{18}$ mols $\mathrm{C}$ for the OAE2 (implied duration $\sim 500 \mathrm{ka}$ ), applying a carbon isotope mass balance modeling approach. Comparing this global number with the estimate from the Tarfaya-LaAaiun Basin implies that approximately $\sim 2 \%$ of the overall global excess OC burial during the OAE2 was deposited in this coastal basin. This number may appear small at first glance. However, it has to be taken into account that the Tarfaya-LaAaiun Basin barely represented $\sim 0,05 \%$ of the total global $\mathrm{C} / \mathrm{T}$ ocean floor (assuming the present-day ocean floor size of $3.1 \cdot 10^{8} \mathrm{~km}^{2}$ with an additional increase of $20 \%$ of continental areas due to the extremely high global sea level during the $\mathrm{C} / \mathrm{T}$ ).

[40] These estimates may have considerable consequences for global OC budget calculations if we consider that thick OC-rich black shales of $\mathrm{C} / \mathrm{T}$ age were not only deposited in the Tarfaya-LaAaiun Basin but all along the northwest African margin (e.g., Sénégal, Agadir and various other smaller basins; Figure 1) and beyond (see Lüning et al. [2004] for review). The exact area of OC-rich strata in these other basins (on and offshore) and their average OC MARs are hardly constrained due to the lack of detailed and high-resolution records, prohibiting a reliable budget calculation for all northwest African coastal basins. Despite these limitations we conclude that large-scale OC burial along the northwest African Shelf significantly contributed to global carbon burial associated with the OAE2. A reliable approximation of its proportion, however, requires additional detailed investigations, comparable to those for the Tarfaya Basin.

\section{Summary}

[41] Cenomanian/Turonian (C/T; 94 Myr ago) black shale successions from the northwest African TarfayaLaAaiun Basin (SW Morocco) have been studied in great detail using trace metal, biomarker and stable isotope data. 
The laminated biogenic sediments from this shelf basin were deposited at high average sedimentation rates $(2-5 \mathrm{~cm} / \mathrm{kyr})$ that enables the investigation of mid-Cretaceous climate and paleoceanography at high temporal resolution with respect to rapid climate change and associated hydrocarbon source-rock formation. The low level of thermal maturity $\left(\mathrm{T}_{\max } 400-425^{\circ} \mathrm{C}\right)$ and the high degree of sulphurization of the organic matter (kerogen) make these black shale successions suitable for advanced inorganic and organic geochemical investigations.

[42] The alignment of the investigated sites is about $120 \mathrm{~km}$ in length and connects the deepest part of the basin (Site S13) via transitional locations (Sites S57 and S75) with a proximal location close to the paleocoastline (Mohammed Plage, Mpl). All investigated black shales are characterized by high hydrogen indices between 400 and 800 (mgHC/gTOC), supporting a dominant marine origin of sedimentary organic matter (type I-IIS kerogen) independent from the bathymetrical setting. The abundant presence of isorenieratane derivatives at all investigated sites confirms the periodic development of photic zone euxinia along with anoxic bottom waters as deduced from on average ten-fold enriched redox-sensitive trace metal concentration (e.g., V, Mo, Ni and Zn, enrichment compared to average shale) in the black shales.

[43] Correlation of $\delta^{13} \mathrm{C}$ isotope profiles (chemostratigraphy) from the investigated sites with those from Eastbourne, Pueblo and Gubio support a revised cyclostratigraphic model for the $\mathrm{C} / \mathrm{T}$ transition at Tarfaya. Following the new time model, the main frequency of the sedimentary cycles was short eccentricity (100 kyr), hence the total duration of the OAE2 was estimated to be $\sim 500 \mathrm{kyr}$.
[44] The multidisciplinary, high-resolution records further support a coupled atmosphere-ocean mechanism that includes repetitive and short-term fluctuations in windinduced upwelling of oxygen-depleted, nutrient-rich intermediate waters coupled to enhanced marine productivity. In response to climate forcing, photic zone and bottom water euxinia alternated with periods of better oxygenation of the water column. This principle scenario is supported by synchronous, high-amplitude fluctuations in accumulation rates of organic carbon, redox-sensitive and sulphide-forming trace metals, and biomarkers. The estimated organic carbon preservation factor and export primary productivity ranged between $5-15 \%$ and $100-$ $200 \mathrm{gC} / \mathrm{m}^{2}$. yr, respectively, which is comparable to modern high-productive continental margin systems. These conditions fostered the massive and long-term carbon burial all along the northwest African Shelf, making this area a significant contributor to the global carbon burial associated with the OAE2.

[45] Acknowledgments. The authors are indebted to the management of Moroccan ONAREP and Shell International (Kees van Kommeren) for providing well material. The manuscript benefited much from valuable discussions from the reviewers Brad Sageman and Paul Wignall and with Michael Böttcher, Hugh Jenkyns, and other members of the European Union-funded C/T-Net Research Training Network. Sabine Kasten, Verena Heuer, and Sebastian Lüning (all University of Bremen) are thanked for fruitful discussions and comments. We acknowledge technical assistance provided by Marianne Baas (NIOZ), Georg Scheeder (BGR), Renate Henning, and Helga Heilmann (University of Bremen). This project was supported by the Deutsche Forschungsgemeinschaft (DFG grants Wa1036/6 and Ku649/9), University of Bremen (FNK grant to Sadat Kolonic), and the European Union's Improving Human Potential Programme under contract HPRN-CT-1999-00055, C/T-Net. The data presented in this study are available at http://www.pangaea.de/PangaVista2?query = kolonics.

\section{References}

Albani El, A. E., D. Vachard, W. Kuhnt, and H. Chellai (1999), Signature of hydrodynamic activity caused by rapid sea level changes in pelagic organic-rich sediments, Tarfaya basin (southern Morocco), Earth Planet. Sci., 329, $397-404$.

Algeo, T. J., and J. B. Maynard (2004), Traceelement behavior and redoc facies in core shales of upper Pennsylvanian Kansas-type cyclothemes, Chem. Geol., 206(3-4), 289-318.

Amblés, A., M. Halim, J. C. Jacquesy, D. Vitorovic, and M. Ziyad (1994), Characterization of kerogen from Timahdit shale (Y-layer) based on multistage alkaline permanganate degradation, Fuel, 73, 17-24.

Arthur, M. A., and I. Premoli Silva (1982), Development of widespread organic carbon-rich strata in the Mediterranean Tethys, in Nature and Origin of Cretaceous Carbon-rich Facies, edited by S. O. Schlanger and M. B. Cita, pp. 7-54, Academic, San Diego, Calif.

Arthur, M. A., W. E. Dean, and L. M. Pratt (1988), Geochemical and climatic effects of increased marine organic carbon burial at the Cenomanian/Turonian boundary, Nature, 335, 714-717.

Arthur, M. A., H. C. Jenkyns, H. J. Brumsack, and S. O. Schlanger (1990), Stratigraphy, geochemistry, and oceanography of organic carbon-rich Cretaceous sequences, in Cretaceous Resources, Events and Rhythms, Background and Plans for Research, NATO ASI Ser. C, Mathematical and Physical Sciences, edited by R. N. Ginsburg and B. Beaudoin, pp. 75120, Kluwer Acad., Norwell, Mass.

Arthur, M. A., W. A. Dean, E. D. Neff, B. J. Hay, J. King, and G. Jones (1994), Varve calibration records of carbonate and organic carbon accumulation over the last 2000 years in the Black Sea, Global Biochem. Cycles, 8, 195-217.

Beckmann, B., P. Hofmann, and T. Wagner (2004), Linking Coniacian-Santonian (OAE3) black shale formation to African climate variability: A reference section from the eastern tropical Atlantic at orbital time scales (ODP Site 959, off Ivory Coast/Ghana), in Source Rock Development: Bioproductivity, Organic Preservation or Sedimentation Rate?, SEPM Spec. Publ., vol. 81, edited by B. Pradier, and N. Harris, in press.

Bice, K. L., and R. D. Norris (2002), Possible atmospheric $\mathrm{CO}_{2}$ extremes of the Middle Cretaceous (late Albian-Turonian), Paleoceanography, 17(4), 1070, doi:10.1029/ 2002PA000778.

Brumsack, H.-J. (1980), Geochemistry of Cretaceous black shales from the Atlantic ocean (DSDP Legs 11, 12, 36, and 41), Chem. Geol., $31,1-25$.

Brumsack, H.-J. (1986), The inorganic geochemistry of Cretaceous black shales (DSDP Leg 41) in comparison to modern upwelling sediments from the Gulf of California, in North Atlantic Palaeoceanography, Spec. Publ., vol. 21, edited by C. P. Summerhayes and N. J. Shackleton, pp. 447-462, Geol. Soc., London.

Caron, M., F. Robaszynski, F. Amedro, F. Baudin, J.-F. Deconinck, P. Hochuli, Von Salis-Perch K. Nielsen, and N. Tribovillard (1999), Estimation de la duree de l'evènement anoxique global au passage Cénomanien/Turonien. Approche cyclostratigraphique dans la formation Bahloul en Tunisie centrale, Bull. Soc. Geol. Fr., 170, 145-160.

DeConto, R. M., W. W. Hay, S. L. Thompson, and J. Bergengren (1999), Late Cretaceous climate and vegetation interactions: The cold continental interior paradox, in The Evolution of Cretaceous Ocean/Climate Systems, Spec. Publ., vol. 332, edited by E. Barrera and C. Johnson, pp. 391-406, Geol. Soc. of Am., Boulder, Colo.

Erba, E., and F. Tremolada (2004), Nannofossil carbonate fluxes during the Early Cretaceous: Phytoplankton response to nutrification episodes, atmospheric $\mathrm{CO}_{2}$, and anoxia, Paleoceanography, 19, PA1008, doi:10.1029 2003PA000884.

Flögel, S. (2002), On the influence of precessional Milankovitch cycles on the Late Cretaceous climate system: Comparison of GCM results, geochemical, and sedimentary proxies 
for the western interior seaway of North America, Ph.D. thesis, Univ. of Kiel, Kiel, Germany.

Gale, A. S., H. C. Jenkyns, W. J. Kennedy, and R. M. Corfield (1993), Chemostratigraphy versus biostratigraphy: Data from around the Cenomanian-Turonian boundary, J. Geol. Soc. London, 150, 29-32.

Gale, A. S., A. B. Smith, N. E. A. Monks, J. R. Young, A. Howard, D. S. Wray, and J. M. Huggett (2000), Marine biodiversity through the late Cenomanian-early Turonian: Palaeoceanographic controls and sequence stratigraphic biases, J. Geol. Soc. London, 157, $745-757$.

Hay, W. W., and R. M. DeConto (1999), A comparison of modern and Late Cretaceous meridional energy transport and oceanology, in The Evolution of Cretaceous Ocean/Climate Systems, Spec. Publ., vol. 332, edited by E. Barrera and C. Johnson, pp. 283-300, Geol. Soc. of Am., Boulder, Colo.

Hay, W. W., et al. (1999), An alternative global cretaceous paleogeography, in The Evolution of Cretaceous Ocean/Climate Systems, Spec. Publ., vol. 332, edited by E. Barrera and C. Johnson, pp. 1-48, Geol. Soc. of Am., Boulder, Colo.

Heinrichs, H., H.-J. Brumsack, N. Loftfield, and N. König (1986), Verbessertes Druckaufschlußsystem für biologische und anorganische Materialien, Z. Pflanzenernähr. Bodenk., 149, $350-353$.

Heyman, M. A. W. (1989), Tectonic and depositional history of the Moroccan continental margin, in Extensional Tectonics and Stratigraphy of the North Atlantic Margins, AAPG Mem., vol. 46, edited by A. J. Tankard and H. R. Balkwill, pp. 323-340, Am. Assoc. of Petrol. Geol., Tulsa, Okla.

Hofmann, P., B. Beckmann, and T. Wagner (2003), A millennial- to centennial-scale record of African climate variability and organic carbon accumulation in the ConiacianSantonian eastern tropical Atlantic (ODP Site 959, off Ivory Coast/Ghana), Geology, 31, $135-138$.

Huber, B. T., R. D. Norris, and K. D. MacLeod (2002), Deep-sea paleotemperature record of extreme warmth during the Cretaceous, Geology, 30, 123-126

Ittekkot, V., B. Haake, M. Bartsch, R. R. Nair, and V. Ramaswamy (1992), Organic carbon removal in the sea: The continental connection, in Upwelling Systems: Evolution Since the Early Miocene, Spec. Publ., vol. 64, edited by C. P. Summerhayes, W. L. Prell, and K. C. Emeis, pp. 167-176, Geol. Soc., London.

Jenkyns, H. C. (1980), Cretaceous anoxic events: From continents to oceans, J. Geol. Soc. London, 137, 171-188

Jones, B., and D. A. C. Manning (1994), Comparison of geochemical indices used for the interpretation of palaeoredox conditions in ancient mudstones, Chem. Geol., 111, 111-129.

Jones, C. E., and H. C. Jenkyns (2001), Seawater strontium isotopes, oceanic anoxic events, and seafloor hydrothermal activity in the Jurassic and Cretaceous, Am. J. Sci., 301, 112-149.

Kennedy, W. J., I. Walaszczyk, and W. A. Cobban (2000), Pueblo, Colorado, USA, candidate global boundary stratotype section and point for the base of the Turonian stage of the Cretaceous, and for the base of the middle Turonian substage, with a revision of the Inoceramidae (Bivalvia), Acta Geol. Polonica, 50, 295-334.

Kolonic, S., J. S. Sinninghe Damsté, M. E. Böttcher, M. M. M. Kuypers, W. Kuhnt,
B. Beckmann, G. Scheeder, and T. Wagner (2002), Geochemical characterization of Cenomanian/Turonian black shales from the Tarfaya Basin (SW Morocco): Relationships between paleoenvironmental conditions and early sulfurization of sedimentary organic matter, J. Petrol. Geol., 25, 325-350.

Koopmans, M. P., J. Köster, H. M. E. van KaamPeters, F. Kenig, S. Schouten, W. A. Hartgers, J. W. de Leeuw, and J. S. Sinninghe Damste (1996), Diagenetic and catagenetic products of isorenieratene: Molecular indicators for photic zone anoxia, Geochim. Cosmochim. Acta, 60, 4467-4496.

Kuhnt, W., and J. Wiedmann (1995), Cenomanian-Turonian source rocks: Paleobiogeographic and paleoenvironmental aspects, in Paleogeography, Paleoclimate, and Source Rocks, Stud. Geol., vol. 40, edited by A. Y. Huc, pp. 213-231, Am. Assoc. of Petrol. Geol., Tulsa, Okla.

Kuhnt, W., J. P. Herbin, J. Thurow, and J. Wiedmann (1990), Distribution of Cenomanian-Turonian organic facies in the western Mediterranean and along the adjacent Atlantic margin, in Deposition of Organic Facies: AAPG Studies in Geology, Tulsa, Oklahoma, USA, edited by A. Y. Huc, pp. 133-160, Am. Assoc. of Petrol. Geol., Tulsa, Okla.

Kuhnt, W., A. Nederbragt, and L. Leine (1997), Cyclicity of Cenomanian-Turonian organiccarbon-rich sediments in the Tarfaya Atlantic Coastal Basin (Morocco), Cretaceous Res., 18 , 587-601.

Kuhnt, W., et al. (2001), Centennial record of Cretaceous paleoceanographic events and sealevel fluctuations in the Moroccan TarfayaLaayoune Basin, Eos Trans., AGU, 82, 361 364.

Kuhnt, W., F. Luderer, S. Nederbragt, J. Thurow, and T. Wagner (2004), Millennial resolution record of the Late Cenomanian oceanic anoxic event (OAE2) in the Tarfaya Basin (Morocco), Int. J. Earth Sci., in press.

Kuypers, M. M. M., R. Pancost, and J. S. Shinninghe Damsté (1999), A large and abrupt fall in atmospheric $\mathrm{CO} 2$ concentration during Cretaceous times, Nature, 399, 342-345.

Kuypers, M. M. M., R. D. Pancost, I. A. Nijenhuis, and J. S. Sinninghe Damsté (2002), Enhanced productivity led to increased organic carbon burial in the euxinic North Atlantic basin during the late Cenomanian oceanic anoxic event, Paleoceanography, 17(4), 1051, doi:10.1029/2000PA000569.

Lamolda, M. A., A. Gorostidi, and C. R. C. Paul (1994), Quantitative estimates of calcareous nannofossil changes across the Plenus Marls (latest Cenomanian), Dover, England: Implications for the generation of the CenomanianTuronian Boundary Event, Cretaceous Res., $14,143-164$.

Larson, R. L., and E. Erba (1999), Onset of the mid-Cretaceous greenhouse in the Barremian-Aptian: Igneous events and biological, sedimentary, and geochemical responses, Paleoceanography, 14, 663-678.

Leckie, R. M., T. J. Bralower, and R. Cashman (2002), Oceanic anoxic events and plankton evolution: Biotic response to tectonic forcing during the mid-Cretaceous, Paleoceanography, 17(3), 1041, doi:10.1029/2001PA000623.

Leine, L. (1986), Geology of the Tarfaya oil shale deposit, Morocco, Geol. Mijnbouw, 65, $57-74$

Luderer, F. (1999), Das Cenoman/Turon Grenzereignis im Tarfaya Becken (SW Marokko),
Ph.D. thesis, Christian-Albrechts-Univ., Kiel, Germany.

Lüning, S., and S. Kolonic (2003), Uranium spectral gamma-ray response as a proxy for organic richness in black shales: Applicability and limitations, J. Petrol. Geol, 26, 153-174.

Lüning, S., S. Kolonic, E. M. Belhadj, Z. Belhadj, L. Cota, G. Baric, and T. Wagner (2004), Integrated depositional model for the CenomanianTuronian organic-rich strata in North Africa, Earth Sci. Rev., 64, 51-117.

Madigan, T. M., M. J. Martinko, and J. Parker (2000), Biology of Microorganisms, 991 pp., Prentice-Hall, Old Tappan, N. J.

Martinis, B., and V. Visintin (1966), Données géologiques sur le bassin sédimentaire côtier de Tarfaya (Maroc méridional), in Bassins Sédimentaires du Littoral Africain, edited by D. Reyre, pp. 13-26, Assoc. Serv. Géol. Afr., Paris.

Meyers, S. R. (2003), Integrated cyclostratigraphy and biogeochemistry of the Cenomanian/ Turonian boundary interval, western interior basin, North America, Ph.D. thesis, 393 pp., Northwestern Univ, Evanston, Ill.

Meyers, S. R., B. B. Sageman, and L. A. Hinnov (2001), Integrated quantitative stratigraphy of the Cenomanian-Turonian Bridge Creek limestone member using evolutive harmonic analysis and stratigraphic modeling, J. Sediment. Res., 71, 628-644.

Nijenhuis, I. A., and G. J. De Lange (2000), Geochemical constraints on Pliocene saprope formation in the eastern Mediterranean, Mar. Geol., 163, 41-63.

Obradovich, J. D. (1993), A Cretaceous time scale, in Evolution of the Western Interior Basin, Spec. Pap., vol. 39, edited by W. G. E. Caldwell and E. G. Kauffman, pp. 379396, Geol. Assoc. of Can., St. Johns, Newfoundland, Canada.

Ohkouchi, N., K. Kawamura, Y. Kajiwara, E. Wada, M. Okada, T. Kanamatsu, and A. Taira (1999), Sulfur isotope records around Livello Bonarelli (northern Apennines, Italy) black shale at the Cenomanian-Turonian boundary, Geology, 27, 535-538.

Paul, C. R. C., S. Mitchell, M. Lamolda, and A. Gorostidi (1994), The CenomanianTuronian boundary event in northern Spain, Geol. Mag., 131, 810-817.

Petit, G. R., and E. E. van Tamelen (1962) Raney Nickel desulphurization, in Organic Reactions, pp. 356-380, John Wiley, Hoboken, N. J.

Prokoph, A., M. Villeneuve, F. P. Agterberg, and V. Rachold (2001), Geochronology and calibration of global Milankovitch cyclicity at the Cenomanian-Turonian boundary, Geology, 29, 523-526.

Ranke, U., U. von Rad, and G. Wissmann (1982), Stratigraphy, facies and tectonic development of the on- and off-shore Aaiun-Tarfaya basin-A review, in Geology of the Northwestern African Continental Margin, edited by U. von Rad et al., pp. 86-105, SpringerVerlag, New York.

Repeta, D. J., D. J. Simpson, B. B. Jorgensen, and H. W. Jannasch (1989), Evidence for anoxygenic photosynthesis from the distribution of bacteriochlorophylls in the Black Sea, Nature, 342, 69-72.

Robaszynski, F., and M. Caron (1995), Foraminifères planctoniques du Crétacé: Commentaire de la zonation Europe-Mèditerranée, Bull. Soc. Geol. Fr., 166, 681-692.

Sageman, B. B., J. Rich, M. A. Arthur, G. E. Birchfield, and W. E. Dean (1997), Evidence 
for Milankovitch periodicities in CenomanianTuronian lithologic and geochemical cycles, western interior USA, J. Sediment. Res., 67, $286-302$

Saiz-Jimenez, C., and J. W. De Leeuw (1984), Pyrolysis-gas chromatography-mass spectrometry of isolated, synthetic and degraded lignins, Org. Geochem., 6, 417-422.

Saiz-Jimenez, C., and J. W. de Leeuw (1986), Lignin pyrolysis products: Their structures and their significance as biomarkers, in $A d$ vances in Organic Geochemistry, 1985, edited by D. Leythauser and J. Rullkötter, pp. 869876, Pergamon, New York.

Schlanger, S. O., and H. C. Jenkyns (1976), Cretaceous oceanic anoxic events: Causes and consequences, Geol. Mijnbouw, 55, 179-184.

Sinninghe Damsté, J. S., and J. Köster (1998), A euxinic North Atlantic Ocean during the Cenomanian/Turonian oceanic anoxic event, Earth Planet. Sci. Lett., 158, 165-173.

Sinninghe Damsté, J. S., W. I. C. Rijpstra, J. W. de Leeuw, and G. W. M. Lijmbach (1994), Molecular characterization of organically bound sulphur in crude oils: A feasibility study for the application of Raney Ni desulphurization as a new method to characterize crude oils, J. High Res. Chromatogr., 17, 489-500.

Sinninghe Damsté, J. S., M. D. Kok, J. Köster, and S. Schouten (1998), Sulfurized carbohydrates: And important sedimentary sink for organic carbon?, Earth Planet. Sci. Lett., 164, 7-13.

Sinninghe Damsté, J. S., S. Schouten, and A. C. T. van Duin (2001), Isorenieratane derivates in sediments: Possible controls on their distribution, Geochim. Cosmochim. Acta, 65, 15571571.

Suess, E. (1980), Particulate organic carbon flux in the oceans - Surface productivity and oxygen utilization, Nature, 288, 260-263.

Thurow, J., M. Moullade, H.-J. Brumsack, E. Masure, J. Taugourdeau-Lantz, and K. Dunham (1988), The Cenomanian/Turonian Boundary Event (CTBE) at Hole 641A, ODP Leg 103 (compared with the CTBE interval at site 398), Proc. Ocean Drill. Program Sci. Results, 103, 587-634.

Tiedemann, R., M. Sarnthein, and N. J. Shackleton (1994), Astronomic timescale for the Pliocene Atlantic $\delta^{18} \mathrm{O}$ and dust flux records of Ocean Drilling Program Site 659, Paleoceanography, 9, 619-638.

Tsikos, H., H. C. Jenkyns, B. Walsworth-Bell, M. R. Petrizzo, E. Erba, I. Premoli Silva, A. Forster, S. Kolonic, T. Wagner, and J. S. Sinninghe Damsté (2004), Carbon-isotope stratigraphy recorded by the Cenomanian/ Turonian Oceanic Anoxic Event: Correlation and implications based on three key-localities, J. Geol. Soc. London, 161(4), 711-719.

van Gemerden, H., and J. Mas (1995), Ecology of phototrophic sulfur bacteria, in Anoxygenic Photosynthetic Bacteria, edited by R. E. Blankenship, M. T. Madigan, and C. E. Bauer, pp. 49-85, Kluwer Acad., Norwell, Mass. van Kaam-Peters, M., E. Heidy, C. I. W. Rijpstra, W. J. de Leeuw, and J. S. Sinninghe Damsté (1998), A high resolution biomarker study of different lithofacies of organic sulfur-rich carbonate rocks of a Kimmeridgian lagoon (French southern Jura), Org. Geochem., 28, 151-177.

von Rad, U., and M. A. Arthur (1979), Geodynamic, sedimentary and volcanic evolution of the Cap Bojador continental margin (NW Africa), in Deep Drilling Results in the Atlantic Ocean: Continental Margin and Palaeoenvironment, Maurice Ewing Ser., vol. 3, edited by M. Talwani, W. Hay, and W. B. F. Ryan, pp. 187-203, AGU, Washington, D. C. von Rad, U., and G. Einsele (1980), MesozoicCenozoic subsidence history and palaeobathymetry of the northwest African continental margin (Aaiun Basin to DSDP 397). The evolution of passive continental margins, Philos. Trans. R. Soc. London, 294, 37-50.

Wagner, T., J. S. Sinninghe Damsté, P. Hofmann, and B. Beckmann (2004), Euxinia and primary production in Late Cretaceous eastern equatorial Atlantic surface waters fostered orbitally driven formation of marine black shales, Paleoceanography, 19, PA3009, doi:10.1029/ 2003PA000898.

Wallmann, K. (2001), Controls on the Cretaceous and Cenozoic evolution of seawater, atmospheric $\mathrm{CO} 2$ and climate, Geochim. Cosmochim. Acta, 65, 3005-3025.

Wedepohl, K. H. (1971), Environmental influences on the chemical composition of shales and clays, in Physics and Chemistry of the Earth, edited by L. H. Ahrens et al., pp. 307-331, Pergamon, New York.
Wedepohl, K. H. (1991), The composition of the upper Earth's crust and the natural cycles of selected metals, Metals in natural raw materials, Natural resources, in Metals and Their Compounds in the Environment, edited by E. Merian, pp. 3-17, John Wiley, Hoboken, N. J.

Wiedmann, J., A. Butt, and G. Einsele (1978), Vergleich von marokkanischen Kreide-Küstenaufschlüssen und Tiefseebohrungen (DSPD): Stratigraphie, Paläoenvironment und Subsidenz an einem passiven Kontinentalrand, Geol. Rundsch., 67, 454-508.

H.-J. Brumsack, Institute for the Chemistry and Biology of the Marine Environment, Carl von Ossietzky University of Oldenburg, P.O. Box 2503, D-26111 Oldenburg, Germany.

E. H. Chellai, Faculté des Sciences Semlalia, Départment de Géologie, Cadi Ayyad University,

B.P. S15, 4000 Marrakech, Morocco.

E. Erba and B. Walsworth-Bell, Ardito Desio Department of Earth Sciences, University of Milan, Via Mangiagalli 34, I-20133 Milan, Italy. A. Forster and J. S. Sinninghe Damsté, Department of Marine Biogeochemistry and Toxicology, Royal Netherlands Institute for Sea Research, P.O. Box 59, N-1790 AB Den Burg, Netherlands.

S. Kolonic, Shell International Exploration and Production B.V., EP Research and Development (EPT-RXR), Kessler Park 1, N-2288 GS Rijswijk, Netherlands. (sadat.kolonic@shell.com)

W. Kuhnt, Department of Geosciences, Christian-Albrechts University of Kiel, Olshausenstrasse 40, D-24118 Kiel, Germany.

M. M. M. Kuypers, Department of Biogeochemistry, Max Planck Institute for Marine Microbiology, Celsiusstrasse 1, D-28359 Bremen, Germany.

H. Tsikos, Department of Geology and Petroleum Geology, University of Aberdeen, King's College, Aberdeen AB24 3UE, UK.

S. Turgeon, Chemical and Isotopic Mass Spectrometry Group, Oak Ridge Nationa Laboratory, Oak Ridge, TN 37831-6131, USA.

T. Wagner, Faculty of Geosciences, University of Bremen, P.O. Box 330440, D-28334 Bremen, Germany. 